AperTO - Archivio Istituzionale Open Access dell'Università di Torino

\title{
Psychology: a Giant with Feet of Clay
}

\section{This is a pre print version of the following article:}

Original Citation:

\section{Availability:}

This version is available http://hdl.handle.net/2318/1740114

since 2022-07-14T07:34:20Z

Published version:

DOI:10.1007/s12124-020-09524-5

Terms of use:

Open Access

Anyone can freely access the full text of works made available as "Open Access". Works made available under a Creative Commons license can be used according to the terms and conditions of said license. Use of all other works requires consent of the right holder (author or publisher) if not exempted from copyright protection by the applicable law. 


\section{Integrative Psychological and Behavioral Science Psychology: A Giant with Feet of Clay --Manuscript Draft--}

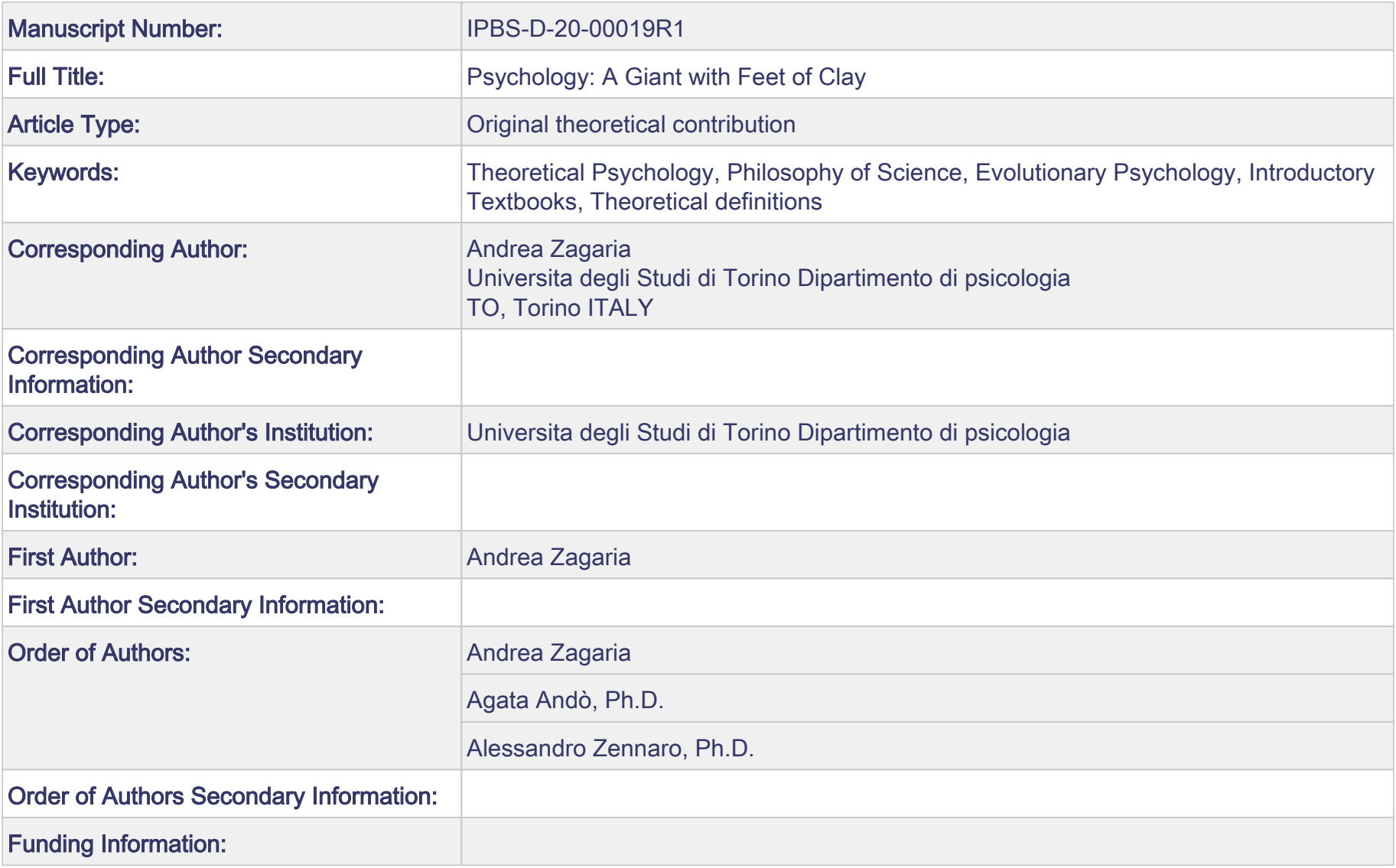


March 2020

Dear Dr. Valsiner,

We would like to thank you for your consideration and interest in our work. We really appreciate the opportunity you are giving us to publish the manuscript even without extra review. Surely, we agree that our article will become a target article. We resubmit the current version of the manuscript.

Best regards

The authors 


\section{PSYCHOLOGY: A GIANT WITH FEET OF CLAY}

Psychology: A Giant with Feet of Clay

Andrea Zagaria, Agata Andò, Alessandro Zennaro

Department of Psychology, University of Turin, Italy

Acknowledgments

We would like to thank Angiola Accardi and Jess Bosi for the linguistic review.

Correspondence concerning this article should be addressed to Andrea Zagaria, Department of Psychology, University of Turin, Turin, 10124. E-mail: zagaria.andrea@ gmail.com

ORCID:

Agata Ando': 0000-0003-0879-133X

Alessandro Zennaro: 0000-0002-2774-307X 


\section{PSYCHOLOGY: A GIANT WITH FEET OF CLAY}

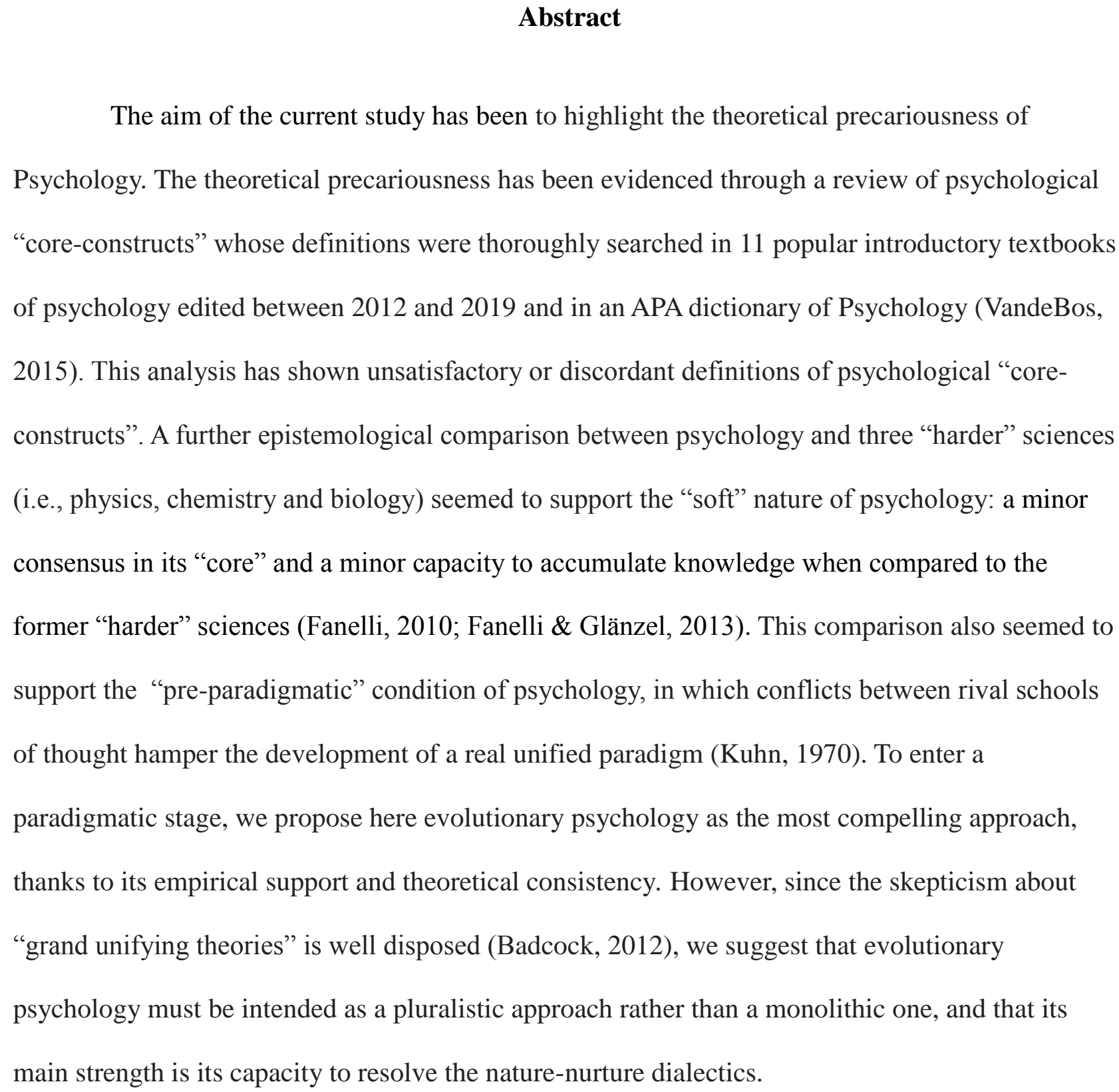

Abstract

The aim of the current study has been to highlight the theoretical precariousness of Psychology. The theoretical precariousness has been evidenced through a review of psychological "core-constructs" whose definitions were thoroughly searched in 11 popular introductory textbooks of psychology edited between 2012 and 2019 and in an APA dictionary of Psychology (VandeBos, 2015). This analysis has shown unsatisfactory or discordant definitions of psychological "coreconstructs". A further epistemological comparison between psychology and three "harder" sciences (i.e., physics, chemistry and biology) seemed to support the "soft" nature of psychology: a minor consensus in its "core" and a minor capacity to accumulate knowledge when compared to the former "harder" sciences (Fanelli, 2010; Fanelli \& Glänzel, 2013). This comparison also seemed to support the "pre-paradigmatic" condition of psychology, in which conflicts between rival schools of thought hamper the development of a real unified paradigm (Kuhn, 1970). To enter a paradigmatic stage, we propose here evolutionary psychology as the most compelling approach, thanks to its empirical support and theoretical consistency. However, since the skepticism about "grand unifying theories" is well disposed (Badcock, 2012), we suggest that evolutionary psychology must be intended as a pluralistic approach rather than a monolithic one, and that its main strength is its capacity to resolve the nature-nurture dialectics.

Keywords: Theoretical Psychology, Philosophy of Science, Evolutionary Psychology, Introductory Textbooks, Theoretical definitions 


\section{PSYCHOLOGY: A GIANT WITH FEET OF CLAY}

"In psychology there are experimental methods and conceptual confusion...The existence of the experimental method makes us think we have the means of solving the problems that trouble us; though problem and method pass one another by"

Wittgenstein L. Philosophical investigations. Oxford: Blackwell, 1953, quot. in Wakefield, 2014, p 38.

\section{A shaky foundation: a lacking concept of "mind"}

Psychology is as an atypical science, as its main object of study is not clearly defined.

Based on its etymology - $\psi v \chi \eta ́ / p s y c h e ́$, soul and $\lambda \gamma_{\gamma} / \operatorname{logos}$, science - it should be the "science of the soul" however, it is somewhat peculiar that the concept of "soul" is strongly rejected by scientists as a unit to be investigated. Psychologists and researchers usually limit their scientific focus to "mind and behavior" (see Table A1). The first signs of confusion may thus be related to the current use of the prefix "psych-" in all the main disciplines in this field, although its etymological meaning is typically refused. However, even if the term "soul" (and thus the "psych-" prefix) was regarded as an irrelevant historical legacy and the contemporary focus was only on the study of "mind and behavior", things would not be better. In fact, the fundamental pillar of psychology, the concept of mind, is neither satisfactorily nor unanimously defined ${ }^{1}$ (Table A1; Wallach e Wallach, 2012). Remarkable efforts have been made in this respect, like the definition proposed by Siegel $^{2}$ (Siegel, 2012, 2016). This formulation might solve the issue in the near future however, it is still not shared by a sufficient proportion of the scientific community. Definitions of mind popular today are

1 Behavior is a less debated term, but still it is not as easy-to-use as it first appears, since it can be intended as "overt" or "covert" or both (Table A1).

2 "The mind is an embodied and relational process that regulates the flow of energy and information" (Siegel, 2012, p.3) 


\section{PSYCHOLOGY: A GIANT WITH FEET OF CLAY}

materialistic - mind interpreted exclusively as a brain activity (e.g. Cacioppo \& Freberg., 2013) or, more often, descriptive-set - mind intended as list of activities moving within it (see Table A1).

However, there are several critical aspects that hinder the materialistic definition (Porcelli, 2009; Benovsky, 2016). Among the most prominent is that there may be emergent properties, i.e. properties that a system shows which are not found in the single parts composing the system itself, and this might happen between mind and brain as well (Tononi, Sporns, \& Edelman, 1994; Edelman \& Tononi, 2001; Edelman, 2003; Bedau \& Humphreys, 2008). Moreover, the brain and the body are directly affected by the mind itself, which operates as a "social organ" that converts relational experiences in the brain and somatic processes (e.g. Tomasello, 1999; 2019; Danese et al., 2011; Lanius, Vermetten \& Pain., 2010; Van der Kolk, 2015). On the other hand, the descriptive-set definition, although more supported than the materialistic one, seems to lack conceptual consistency (Table A1). Activities (such as thinking and reasoning) and concepts (such as cognition and emotions) included to define the mind are themselves circularly defined by the formulation of mind itself, therefore resulting in a vacuous recursion (Table A1-A6). For example, "mind" is often conceived as a list of activities that includes "thinking" or "thoughts" (Table A1), when, at the same time, the definition of "thinking" generally always refers to its "mental" nature as a characterizing feature (Table A5).

Most psychologists (more often implicated in practice rather than in theory) consider the definition of mind as a matter of no significance, leaving it to the philosophers and therefore unconsciously adopting an ontological approach that could insidiously affect their own clinical or scientific activity.

\section{An unsteady building}

This first fragile condition (that is a lacking concept of mind) is necessarily followed by many cumbersome consequences: most of the psychological constructs are not satisfactorily defined (see Table A2-A6). The cornerstones upon which psychological science is built seem to falter or fit 


\section{PSYCHOLOGY: A GIANT WITH FEET OF CLAY}

only in the context in which they have been implemented (Staats, 1999). The idea of "languagegame" (Wittgenstein, 1953) (i.e., the comprehension of a given word exclusively in the context in which it is used) could be called into question to depict this condition. Nevertheless, if the "language-game" theory works in semantics, it does not in the field of science, as it undermines many fundamental processes of the scientific enquiry, like replicability and inter-subjectivity (Wilson, 1999). Cognition, consciousness, emotion, intelligence, mind and thinking, are concepts usually used by psychologists and psychiatrists around the world. Nevertheless, no one seems to agree on what they really are (as reported from Table A1 to Table A6). Several other terms might be less debated, presenting a larger degree of agreement (i.e., attention, behavior,decision-making, language, learning, memory, motivation, reasoning, perception, problem-solving, and sensation).

However, a real accordance is far from reached; more importantly, these concepts are often ambiguous, overlapping and circularly defined by the former concepts quoted above which, in our opinion, lack a satisfactory conceptualization (see tables A1-A6). All this results in non-conclusive definitions. The reasons that may account for such theoretical chaos may be attributed to the recent classification of Psychology as a science (Fernald, 2007; Goldfried, 2018) as well as the peculiar epistemological status of this discipline, dealing with subjectivity and objectivity at the same time (Jung, 1947; Gaj, 2016) ${ }^{3}$ or the degree of high complexity in which is involved (Staats, 1999; Fernald, 2007; Fanelli \& Glänzel, 2013).

\section{The clinical war: conflicts between "schools of thought"}

Scientific and clinical psychology are controversially related to each other (Meehl, 1954;

Miller, 2001; Gaj, 2016). This contrast finds its reason in the peculiarity of the clinical context in which the nomothetic scientific approach conflicts with the necessary enhancement of the patient's

3 The objective study of subjective experience (e.g. consciousness) presents par definition epistemological difficulties since it compares apparently irreducible entities (objective properties measured by the scientific enquiry) with inner and private mental states (sometimes referred to as qualia; states that cannot be measured and objectivised). 


\section{PSYCHOLOGY: A GIANT WITH FEET OF CLAY}

idiographic perspective. Within this controversy, the theoretical chaos in the psychotherapeutic field is perhaps much wider (Melchert, 2016; Goldfried, 2018). Although conciliatory efforts do exist, most of the psychotherapeutic concepts are used in the specific context in which they were first formulated and are being ignored, even mocked, by other "schools of thought" (Krantz, 1987; Tracy, Robins \& Gosling, 2005). The definition of psychotherapeutic constructs is just as confusing. The same phenomenon, substantially unmodified, is "discovered" and re-named several times (Goldfried, 2018) [a phenomenon we propose here to label "nominomania", a neologism we have coined in this regard]. Furthermore, the term "school of thought", at least if taken literally, seems to be more appropriate in spiritual, political or ideological fields, not in scientific areas.

In this regard, often unification claims, that have a long and diverse history in psychology (e.g. Krantz, 1987; Royce, 1987; De Groot,1990; Kimble, 1994; Anderson, 1996; 2008; Staats, 1999; Sternberg \& Grigorenko, 2001; Sternberg, 2005; Henriques, 2004, 2011; Glenberg, 2010; Gaj, 2016; Melchert, 2016) have been intended as a dangerous threat to scientific pluralism (e.g., Toulmin, 1987; Gergen, 1988; McNally,1992; Kukla, 1992 ; Kirschner, 2006). This happened, in our opinion, because the concept of scientific pluralism has been mistaken for the unrestrained proliferation of perspectives. As it has been recently proved, this uncontrolled proliferation risks being harmful to scientific integrity and progress (Balietti, Mäs, \& Helbing, 2015).

\section{The current study}

The aim of our study has been to take a "picture" of the core-concepts of psychology and to consequently attest the way that they are commonly conceived and explained in introductory books, in order to attempt an "epistemological assessment" of the discipline.

This has been pursued through an examination of 11 popular introductory textbooks of psychology published between 2012 and 2019 and the APA dictionary of psychology (VandenBos, 


\section{PSYCHOLOGY: A GIANT WITH FEET OF CLAY}

$2015)^{4}$. Every concept's definition has been carefully researched along with the introductory textbooks and the dictionary, and it has been reported in tables (A1-A6) along with the page it is presented upon, the authors and, when needed, the additional references made by the authors themselves.

The analysis of the introductory books has been chosen because, as written by Staats (1999, p.5) about controversies about a unifying theory, “(...) specialists in the various fields consulted and used only works in that specialty. The only books that treated the several fields of psychology were introductory psychology texts". In our opinion, this situation seems to be unchanged. Furthermore, Fanelli (2010, p.2) explicitly states that "the core [of research] is (...) identifiable with the content of advanced university textbooks (...)".

In the philosophy of science, the analysis of introductory textbooks has historically been an accessible tool used to roughly assess the state of a discipline (Cole, 1983, 1996, 2001). This analysis is extraordinarily still used today by many psychologists with either epistemological, educational or political aims and focuses (e.g. Roeckelein, 1996, 1997; Zechmeister \& Zechmeister, 2000; Habarth, Hansell \& Grove, 2001; Simonton, 2004, 20065; Costa \& Shimp., 2011; Kissee, Isaacson \& Miller-Perrin, 2014; Griggs \& Christopher, 2016; Whaley, Clay \& Broussard, 2017; Whitehead III, Smith \& Losonczy-Marshall, 2017; Ferguson, Brown, TorresBrown \& Torres, 2018; Warne, Astle \& Hill, 2018). The analysis of introductory books has also been implemented by scholars from other sciences, including informatics (McMaster, Rague, Sambasivam, \& Wolthuis, 2019), statistics (Ravinder \& Misra, 2016; Dunn, Carey, Farrar, Richardson \& McDonald, 2017), chemistry (Nelson, Kumar \& Ramasamy, 2015), biology (Colosi, 2000; Bednekoff, 2005; Wright, Cardenas, Liang \& Newman, 2017) and sociology (Manza \& Van Schyndel, 2000; Keith \& Ender,

4 Someone could argue for the exclusion of influential sources, both due to their historical importance (e.g. William James, Wilhelm Wundt, John Watson...) or due to their specialization in specific psychological sub-disciplines (e.g. Noam Chomsky, Burrhus Skinner in language studies, Jaak Panksepp and Antonio Damasio in emotion studies). However, such criticism would not adequately consider the organizing rationale adopted here. Our interest lies in what is the "core - knowledge" of contemporary psychology operationalized in popular (and recent) introductory textbooks.

5 In Simonton's studies, the analysis of introductory books is just one part of a wider procedure. 


\section{PSYCHOLOGY: A GIANT WITH FEET OF CLAY}

2004; Shin, 2014).

\section{Method}

Firstly, we examined the definitions of the following fundamental terms:

1. psychology

2. mind

3. behavior

The selection of further psychological core-constructs was based on the category of "cognitive functions". "Cognitive functions" are, in fact, often the main objects of study of scientific psychology. However, since there is no clear definition of cognition (see Table A2), we failed to find a specific list of cognitive functions anywhere ${ }^{6}$. We therefore adopted the wider meaning of cognition, "information processing in the brain" (Zimbardo, Johnson \& McCann, p.190).

A list of cognitive functions is presented below. If their exclusive selection is no doubt somewhat arbitrary, all these terms are usually grouped under the umbrella-term "cognitive functions"

(Newell, 1994, p.15; Reisberg, 2013, p.3-5; Ochsner \& Kosslyn, 2013, p.7-8) ${ }^{7}$

4. attention

5. cognition

6. consciousness

7. decision-making

8. intelligence

6 Even when they are classified in "higher" and "lower" [the latter being more automatic and reflex-type than the former, requesting an "effortful" process (Frith \& Dolan, 1995)], no clear list is presented.

7 "Intelligence" and "language" are two atypical concepts: they cover broader phenomena than those strictly grouped under the label "cognitive functions". Language is sometimes conceived as a full-fledged cognitive function (e.g. Newell, 1994, p. 441; Ochsner \& Kosslyn, p.7) and sometimes it is not, but is nevertheless considered as strongly related to cognitive functioning (e.g. Reisberg, 2013, p.2). Intelligence is a wide concept, often assumed to underlie most cognitive process, or, more specifically, to be a sort of general "cognitive ability" (Bernstein et al., 2012, p.373), a varying potential of cognitive processing. Also, in this case, its close conceptual relatedness to the "cognitive functions" accounted for its inclusion in this list. For conceptual clarity and exhaustiveness, we included also the term "cognition" itself, even if of course it is not directly cited by these authors (because it is implicitly assumed to be the umbrella-term under which all these concepts are grouped). 


\section{PSYCHOLOGY: A GIANT WITH FEET OF CLAY}

9. language

10. learning

11. memory

12. perception

13. problem solving

14. reasoning

15. thinking

Though they are not usually considered "cognitive functions", in the end we included the terms due to their importance in everyday psychology:

16. emotion

17. motivation

18. sensation

Problems arising in the analysis of the specific concepts (e.g. the subdivision of memory into working memory, long term memory and short-term memory) have been described table by table. All the tables are presented in Appendix A, while a summary is included in the results section.

\section{Results}

Below are the main definitions of core concepts in psychology highlighting the main elements shared by authors and the texts we selected (for all details, see Appendix A).

Psychology is literally defined by most introductory books (7/12) as the "scientific study of mind and behavior". The remaining definitions are substantially similar, despite the fact that "mind" is indicated through synonyms (e.g. "mental processes", "thought", "cognitive processes") (3/12). Finally, in two definitions "mind" and "behavior" are listed along with the term "brain" or "brain processes". As "mind" and "behavior" are transversely mentioned as the two pillars of scientific psychology, it follows that they must be the next elements to be analyzed.

Mind is not defined by half of the introductory books. Four sources define it as a list of 


\section{PSYCHOLOGY: A GIANT WITH FEET OF CLAY}

activities (e.g. thinking, remembering, feeling...). Two bibliographic sources define it as "brain activity" or "brain and behavior".

Behavior is not defined by half of the introductory books. The other sources define it globally as something that can be directly observed, but it is not clear whether it is intended as "overt" (external actions), "covert" (internal "actions", such as an action potential), or in both the meanings. Then, our analysis focused on the so-called "cognitive functions", presented here in alphabetical order.

(Selective) attention: its definitional core seems to converge on the concept of "focus of (restricted) cognitive resources", but the definitions vary widely, often referring to "mental processes", "conscience", "awareness" or "perception". Four sources do not define the phenomenon.

Consciousness, along with intelligence, is one of the most debated terms in psychology. Definitions largely vary, but ten out of the twelve sources tautologically define consciousness as "awareness", one vaguely defines it as the "the brain process that creates our mental representation" and finally one source does not define it.

Cognition is so variously formulated that it is difficult to summarize its definitions. Broadly, cognition seems to be an "umbrella-term" under which all the activities traditionally considered to be "cold cognition" are grouped: e.g. information processing, thinking, reasoning, problem solving, understanding, knowing. Two sources consider the cognition as a mere synonym of "thinking" and three sources do not define it.

Decision-making is not defined by seven sources. The remaining five sources seem to converge on the process of "selecting among different alternatives", but often referring to other phenomenon like "cognition", "cognitive processes" or "evaluation".

Intelligence is probably one of the most debated terms in the history of psychology. Definitions (10/12) are so rich and different that summarizing them is nearly impossible, but they 


\section{PSYCHOLOGY: A GIANT WITH FEET OF CLAY}

almost all systemically refer to other psychological constructs (e.g. reasoning, understanding, problem-solving...) Two sources do not define the construct.

Language is variously defined, but almost all the definitions seem to converge on the manipulation of "symbols" (which are not defined) "combined" via a "set of rules" in order to "communicate" ("communication" is also scarcely defined). The content of the communication is indicated as "thoughts", "feelings", or "ideas". One source does not define language.

Learning. All the definitions seem to converge on the "modification" of "behavior", "mental processes" or "information" of an individual through "experience" (which is never defined).

Memory. Most of the definitions seem to converge on the "ability" (or "capacity") to "acquire information", to "retain" it "over time" and to "retrieve" it if needed. Two sources do not define memory.

Perception: All its definitions seem to converge on the "mental interpretation" (which is never defined) of "sensations".

Problem-solving is not defined by five sources. The concept of "goal" is given different meanings including "use of information", "cognitive processes", "thinking”, "behavior", "reasoning", "higher mental functions" and "active efforts".

Reasoning is not defined by six sources. The remaining definitions largely vary so that it is impossible to summarize them. What seems to emerge is a sort of "abstract" and "logical" process compared to problem-solving, which seems to be more pragmatic in its nature.

Thinking is a widely used term but in our opinion, is still vague. Five sources largely vary but converge on the concept of "(mental) manipulation" of "(mental) representations" (which are never defined). A lot of concepts are listed along with them, such "cognitive processes", “information", "inferences", "conclusions", "ideas", "images" and "scripts". One source defines it 


\section{PSYCHOLOGY: A GIANT WITH FEET OF CLAY}

very vaguely as "any mental activity or processing of information". Five remaining sources do not define the phenomenon. One last one merely defines it as a synonym of "cognition". Finally, we focused our analysis on three terms that are very important in everyday psychology: emotion, motivation and sensation.

Emotion is so variously defined that is very difficult to summarize. Some characteristics seem nevertheless to emerge (physical arousal, positive or negative experience, stimulus-related phenomenon, response behavior and cognitive appraisal), but they are so unequally considered from definition to definition that it is impossible to declare them as defining features.

Motivations are variously defined. Nevertheless, the definitions seem to converge on the concepts of "drive" (or "influence", "force", "urge", "factor", "need", "desire", "disposition", "impetus" or "cause") to direct "behavior" (or "activities" or "actions") toward a "goal" (or "purpose", "needs" or "psychological wants"). It is therefore not clear if motivations are based on "causes", on "purposes" or on both, but this controversy is probably more philosophical than psychological.

Sensation. All its definitions seems to converge on the "stimulation" of the "sense organ" or "sense receptors".

\section{Discussion}

As reported in all tables included in this work, the lack of consensus about the coreconstructs of psychology is ubiquitous. Analogous considerations about the unsatisfactory nature of definitions of constructs have already been made in sociology (Wallace, 1988). However, a coerced imposition of definitions would probably change nothing "unless the consensus on the meaning and significance of the concepts was real and natural" as written by Cole, again about sociology (1994, p.137). Cole's claim probably stems from the fact that a consensus in formulating constructs cannot be reached if no paradigm is shared between the formulators (i.e. if they do not "filter" the world through the same "lenses", resulting in a "real and natural" "consensus"). We think therefore, that a consensus could be reached by embracing a theoretical framework (Royce, 1987). We do not share 


\section{PSYCHOLOGY: A GIANT WITH FEET OF CLAY}

the ideas that unifying psychology is a more "disciplinal maneuver" than an "epistemological act" (Stam, 2004), that it can be unified albeit in a "multi-paradigmatic" way (Sternberg, 2001); that it can be unified via "inter-field" and "inter-level" theories (Staats, 1991) or that it is destined never to be unified (Koch, 1993). In our opinion, the unification attempt might be successful as long as different scientists would not disagree on the "core" concepts main structures and functions.

In this regard, we believe that the most compelling candidate to try and fix this gap is evolutionary psychology: it may be designed to address the demands reported above in the most comprehensive way. ${ }^{9}$ In fact, evolutionary psychology, in line with evolutionary biology, tries to answer Tinbergen's (1963) "four questions": 1) mechanism: "What is the structure of the trait; how does it work?" 2) ontogeny: "How does the trait develop in individuals?") (Nesse, 2013, p.681) 3) phylogeny: "What is the system's history? How has it changed through evolution, and how does it differ between related species?" and 4) adaptation: "Why did the system evolve into its present form? What evolutionary advantages did it provide?" (Del Giudice, 2018, p.42). The answers to the first two questions are usually labeled as proximate because they explain how an "organism works in present" (Del Giudice, 2018, p.42). The answers to the third and fourth questions are labeled as ultimate because they explain how an organism reached its current biological functioning from a "historical" perspective.

Ultimate and proximate explanations are complementary; together, they can offer a satisfactory explanation about the whole functioning of psychological mechanisms. Nevertheless, the typical approach in medicine and psychology is to focus exclusively on the proximate ones (Del Giudice, 2018). Evolutionary psychology could thus be the most complete approach because it is the only one that manages to integrate answers to all four questions. Furthermore, it dissolves the long-standing debate of nature vs nurture and it is a credible bridge between scientific and clinical

9 Henriques (2017) claimed that "every major perspective in psychology currently accepts evolutionary theory" (p.393), treating it as a simple theory and not as a meta-theory, which according to him is something different and can be represented in his "Tree of Knowledge" (Henriques, 2003). We disagree with Henriques both in regard to the "acceptance" of evolutionary theory in the context of psychology and in regard to the consideration of evolutionary psychology as a theory, while we explicitly claim that it is a meta-theory. 


\section{PSYCHOLOGY: A GIANT WITH FEET OF CLAY}

psychology, which manages to connect in a continuum of normal vs abnormal functioning, offering a compelling explanation for many mental disorders (Nesse, 2015; Brüne, 2015; Del Giudice, 2018). Some critical points must be addressed before this issue is analyzed more thoroughly.

First critical aspect: is it any different in the so-called "harder" sciences?

One could argue whether this conceptual vacuum is also present in other sciences. It is widely accepted that the scientific inquiry is a process of constant reviewing and redefining of its constructs (Kuhn, 1970), so a similar situation could be evidenced in other branches of knowledge. However, there seem to be different degrees of "uncertainty" varying from one science to another. This has been defined by many as the contrast between "hard" and "soft" sciences. What is meant by "hard" science? There is no univocal definition, though, the key idea is that hard sciences typically show a larger consensus in their "core" [the "core" is " the corpus of agreed upon theories and concepts that researchers need to know in order to contribute to the field" (Fanelli, 2010, p.2)] (Zuckerman \& Merton,1972; Cole, 1983, 1994; Simonton, 2006; Fanelli, 2010; Fanelli \& Glänzel, 2013). Furthermore, hard sciences seem to prove a stronger capacity to accumulate knowledge, relying more "on the significance of new knowledge and the continuing relevance of old" (Fanelli \& Glanzel, 2013, p.1; Simonton, 2002).

By contrast, soft sciences seem to have less consensus in their core, a minor capacity to accumulate knowledge and a minor adherence to the data and theories, who "speak less from themselves" and are more likely to be influenced by non-cognitive factors, such as the academic prestige, political and ideological beliefs, and so on (Fanelli \& Glänzel, 2013). There is no qualitative difference, rather a "graduation" between these two "groups" (Fanelli \& Glänzel, 2013). This contrast, recently seen as "controversial, if not even offensive", nevertheless seems "to capture an essential feature of science" (Fanelli, 2013, p.1).

Psychology is both historically (Simonton, 2004) and contemporarily (Fanelli, 2010;

Fanelli \& Glänzel, 2013) considered as "soft" when compared to "hard" sciences such as physics, biology or chemistry. These sciences are often compared to psychology theoretically and 


\section{PSYCHOLOGY: A GIANT WITH FEET OF CLAY}

practically (Popper, 1972; Lilienfeld, 2014); moreover, they are more frequently believed to be "stronger" than psychology both by lay people and by scholars (Janda, England, Lovejoy \& Drury, 1998). In order to assess if this difference in "hardness" is real, we conducted a comparison between the psychological science and these three sciences (physics, biology, chemistry).

Ideally, two considerations, respectively labeled synchronic and diachronic, must be addressed in order to draw the comparison. First, it must be examined whether, within a specific time interval (often the most recent), the degree of "hardness" in physics, biology and chemistry is meaningfully different than the one in psychology [synchronic]. Second, it must be examined whether, along with the scientific progress evolving over time, the "significance of new knowledge and the continuing relevance of old" is really different between psychology and these other three sciences [diachronic].

A synchronic point of view. The first question seems to have been answered by empirical literature, which, by using sophisticated bibliometric and statistical methodologies, has empirically demonstrated what only used to be a conceptual speculation (Simonton, 2002, 2004; Fanelli, 2010; Fanelli \& Fanelli \& Glänzel,2013). Simonton's first paper (2002) is an attempt to summarize a "systematic statistical comparison" (Simonton, 2002, p.352) of all previous research conducted in the "epistemological assessment" of the hierarchy of sciences, in order not to "to address the substantive question piecemeal" but rather to get a global reliable index. For example, different studies previously conducted dealt with different disciplines. Also, the "various alternative rankings of the sciences" had "not [been] subjected to any rigorous statistical test of the degree to which they might be in agreement" (Simonton, 2002, p.352). The disciplines considered in this study were physics, chemistry, psychology and sociology. With such a rigorous methodology, the parameters considered in this study have been:

1.Theories-to-laws ratio. "Roeckelein's (1997) measure called "theories-to-laws ratio" (number of cited theories divided by number of cited laws in textbooks). (...) The ratio will be well- 


\section{PSYCHOLOGY: A GIANT WITH FEET OF CLAY}

balanced, i.e., show low values, for the "natural" sciences (physics, chemistry, biology) and be poorly balanced, i.e., show high values, for the "social" sciences (anthropology, sociology)" (Roeckelein, 1997, p. 131). The higher the ratio, the higher the "softness".

2. Consultation rate. Suls \& Fletcher (1983) index, based on Leon Festinger's (1954) social comparison theory. In a nutshell, the consultation "with colleagues before submitting a paper for publication in the discipline's journal (...), revealed in the acknowledgment sections of the published articles" (Simonton, p.351) is assumed to reflect the uncertainty about core topics of the discipline. "The specific measure was the number of persons acknowledged adjusted for the number of authors" (Simonton, 2002, p.352). Similar to the previous index, the higher the ratio, the higher the "softness".

3. Early impact rate. All the remaining criteria came from Cole (1983). The first is the "proportion of scientists under 35 whose work received more than the mean number of citations for their field" (S. Cole, 1983, p. 118; i.e., fields that incorporate most quickly the work of young scientists are assumed to rank higher in the hierarchy) "(Simonton, 2002, p.354).

4. Peer evaluation consensus $I$. The fourth criterion is supposed to evaluate consensus, i.e. "the "consensus on evaluating scientists by field" (S. Cole, 1983, p. 120), where 60 scientists per field were rated by colleagues in the same discipline (the consensus was gauged by the mean standard deviation of the ratings)".

5. Peer evaluation consensus II. The fifth criterion is supposed to evaluate the consensus as well, i.e. "the consensus gauged by asking scientists to mention those who "have contributed the most in past two decades" (S. Cole, 1983, p. 120; the specific index is the percentage of "mentions received by 5 most mentioned names").

6. Citation concentration. The "concentration of citations to research articles" (S. Cole, 1983, p. 122; using the Gini coefficient) (Simonton, 2002, p.354). "If the citations are all concentrated in a single article, then the disciplinary consensus must be very high, whereas if it is 


\section{PSYCHOLOGY: A GIANT WITH FEET OF CLAY}

more evenly distributed across articles, then the consensus must be minimal" (Simonton, 2002, p.353).

The overall results (for further detail, see Simonton, 2002) confirmed the "soft" status of psychology compared to physics and chemistry.

Simonton's second paper (2004) is aimed at replicating and expanding the former study. It deals specifically with physics, chemistry, biology, psychology and sociology. Two further primary criteria have been added to those mentioned above:

1. The obsolescence rate by McDowell (1982). "On the basis of the relative frequency of citations to older publications, McDowell (1982) determined the rate at which knowledge becomes obsolete for the disciplines (...) The specific measure used here was his calculation of the expected publication cost of interrupting a career for just 1 year. (...). For example, if their career is interrupted for a single year (e.g., by administrative work or parental or health leave), the output of physicists will be cut by about $17 \%$, whereas the productivity of psychologists will be cut by about $10 \%$ (because physicists will have much more "catching up on the literature" to do before they can resuscitate their careers) (Simonton, 2004, p.61).

2. Graph prominence: "Cleveland (1984) assessed the extent to which graphs appear in articles published in the professional journals, demonstrating that graphs are more extensively used in the "hard" disciplines (see also Smith et al., in press)."

The peer evaluation consensus II was removed due to methodological issues. Other "secondary measures" are considered, even if not essential for the main statistics because they are not completely objective but nevertheless they are "useful for validating the results obtained from the primary measures" (Simonton, 2004, p. 62) ${ }^{10}$. The results demonstrated that Psychology is "softer" than the traditional "harder" sciences according to these parameters.

Fanelli's first study (2010) focused on the "confirmatory bias". In other words,

10 Lecture disfluency, Citation immediacy, Anticipation frequency, Age at receipt of Nobel Prize, rated disciplinary hardness (for further details, see Simonton 2004). 


\section{PSYCHOLOGY: A GIANT WITH FEET OF CLAY}

"researchers in "softer" sciences should have fewer constraints to their conscious and unconscious biases, and therefore report more positive outcome" (Fanelli, 2010, p.1). This study includes a broad range of sciences, including physics, chemistry, biology and psychology. The results are clear: "the odds of reporting a positive result were around 5 times higher among papers in the disciplines of Psychology and Psychiatry and Economics and Business compared to Space Science, 2.3 times higher in the domain of social sciences compared to the physical sciences, and 3.4 times higher in studies applying behavioral and social methodologies on people compared to physical and chemical studies on non-biological material". For further methodological issues, see the original paper (Fanelli, 2010).

Fanelli \& Ganzel's paper (2013) is more sophisticated. About 30, 000 papers from different disciplines (including physics, chemistry, biology and psychology) have been analyzed through nine indexes:

1. Number of authors. "Research teams are almost by definition built around a consensus on objectives and methods. Moreover, the ability to study a problem with greater accuracy and detail leads to a specialization of roles, making collaboration essential(...) The hardness of a field, therefore, should be manifest in the size of its research teams" (Fanelli \& Ganzel, 2013, p.4).

2. Length of article. "When consensus is lower, papers must put greater efforts in describing the background, justify their rationale and approach, back up their claims and extensively discuss their findings (...) Longer introductions, and generally longer papers, should therefore characterize softer research. We measured the total number of pages" (Fanelli \& Ganzel, 2013, p.5).

3. Number of references. "For reasons similar to those that make an article longer, references to previous literature should also be more numerous in low-consensus fields (...)"

4. References to monographs. "Scholars in the humanities and social sciences still frequently choose to publish books rather than papers". 


\section{PSYCHOLOGY: A GIANT WITH FEET OF CLAY}

5. Age of references. "Having noted that some sciences "metabolize" the literature more rapidly, Derek de Solla Price (1970) proposed an index, which measures the proportion of cited references published in the five years preceding the citing paper. The faster the "metabolism", the "harder" the science.

6. Diversity of sources. "When scholars agree on the relative importance of scientific problems, their efforts will concentrate in specific fields and their findings will be of more general interest, leading to a greater concentration of the relevant literature in few, high-ranking outlets" (Fanelli \& Ganzel, 2013, p.6).

7. Relative title length. "Linguistic analyses of scientific papers noted that the number of substantive words in titles tended to be longer and to correlate with an article's total length in harder fields (...). We measured the total number of words, divided by total number of pages.”

8. Use of first person. "Scientists aim at making universal claims, and their style of writing tends to be as impersonal as possible. In the humanities, on the other hand, the emphasis tends to be on originality, individuality and argumentation, which makes the use of first person more $\operatorname{common}(\ldots) "$

9. Sharing of references. "Authors that cite a common literature almost by definition are exhibiting a common cognitive background. The sharing of references between papers, therefore, is perhaps the most direct expression of scholarly consensus. Of the various techniques available to analyse citation networks, the most likely to reflect this parameter is bibliographic coupling, in which a network link is draw between two papers that cite the same reference(...)" (Fanelli \& Ganzel, 2013, p.6-7).

Once again, the hierarchy of sciences (with psychology/psychiatry as "soft" sciences) has been confirmed (for more detail, see Fanelli \& Ganzel, 2013). Psychology, often alongside psychiatry, really seems to be "softer" than physics, chemistry and biology. As we believe that the experimental method applied to philosophy is a valid tool to settle conceptual disputes (Griffiths \& 


\section{PSYCHOLOGY: A GIANT WITH FEET OF CLAY}

Stotz, 2008; Sytsma \& Buckwalter, 2016), we have mainly based our considerations on this empirical data. Reasonably, it could be argued that this empirical data is not sufficient to exclusively resolve the issue. It could be said, for example, that even the fundamental concept of

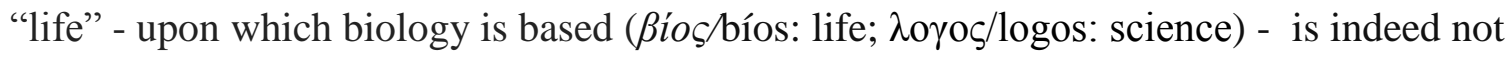
unanimous, as said by Lilienfeld (2004) against Henriques (2004). In our opinion, this conceptual claim does not take into account the broader epistemological context of biology; the latter clearly seeming more "solid" than the context of psychology as demonstrated by the studies mentioned above. Similar considerations could be made on analogous controversies in physics and chemistry.

A diachronic point of view. The second issue is about the historical discontinuity ("the significance of new knowledge and the continuing relevance of old"), or as Simonton (2002, p. 355) put it, the "intra-disciplinary advancement". A historical analysis in psychology is inevitably preceded by many conceptual problems. First, does the word "paradigm(s)" fit the "schools of thought" in a proper sense? The answer is largely controversial, and some authors have fairly proposed to use the word "sub-discipline" instead (Friman, Allen, Kerwin, \& Larzelere, 1993), a suggestion that has been adopted by other studies in this field alongside the term "school" (Robins, Gosling \& Craik, 1999; Tracy et al., 2005; Norcross, Karpiak \& Santoro, 2005; Spear, 2007). Here, we will use the word "approach", "theory" or "trend" because the term "sub-discipline" or "school" might implicitly suggest that these views are completely incompatible with each other when they are not.

Consistent with the considerations about the experimental method applied to conceptual disputes, we based our commentary only on existing empirical literature on "historical trends" in psychology (Robins et al., 1999; Tracy et al., 2005; Norcross et al., 2005; Spear, 2007). ${ }^{11}$ These studies assessed the prominence of every theory thanks to particular bibliometric measures;

11 Moreover, our focus has been exclusively on these studies because we wanted to avoid the systematic positive distortion of a researchers' point of view towards his own theory (Tracy et al., 2005). This bias could potentially affect all qualitative historical analysis. Furthermore, empirical analysis appears to be a more intersubjective source than qualitative analysis (Simonton 1990, 2006). 


\section{PSYCHOLOGY: A GIANT WITH FEET OF CLAY}

assuming the more an approach is cited the more it is prominent, they estimate the "citation pattern" of every theory and compare one to each other in order to determine what "rises", what "is in decline" and so on.

This stance obviously limited ${ }^{12}$ (but also grounded) our conclusions in the period in which bibliometric analysis has been done, i.e., after the 1950's. It has also restricted the analysis of just four approaches (psychoanalysis, cognitivism, behaviorism and neuroscience). Spear (2007) also considered the neuro-cognitive theory and Norcross and colleagues (2005), whose analysis was about clinics, also mentioned the humanistic and integrative/eclectic approaches. Cognitivebehavioral theory, gestalt theory, evolutionary psychology, alongside other important approaches and historical traditions - e.g. structuralism and functionalism - have been deliberately ignored, making our conclusions simpler (and perhaps more simplistic). Furthermore, the approaches have been considered in a "monolithic fashion", while it is widely known, for example, that psychoanalysis is subdivided into many different approaches.

Despite all these limitations, since the intention was to have an overall idea about conflicts between different theories, we believe that such analysis may satisfactorily reach our aim. In summary, what emerges from these papers is that the neuro-cognitive approach is undoubtedly the most popular nowadays in psychology (Tracy et al., 2005; Spear, 2007). On the other hand, in clinical psychology, cognitive and eclectic/integrative approaches appear to be the most implemented (Norcross et al., 2005). Although the cognitive approach is a very common and shared, it seems to be far away from being a real "paradigm". (Tracy et al., 2005; Spear, 2007).

A historical comparison with the other sciences is therefore unlikely to be made. No real paradigm seems to be identifiable in the "recent" history of psychology (post-1950). It is very likely that no real paradigm (in a kuhnian sense) existed either in "past" psychology (1879-1950) as many suggested (James, 1894; Heidbreder, 1933; Cronbach, 1957). Since no real psychological paradigm 


\section{PSYCHOLOGY: A GIANT WITH FEET OF CLAY}

(in a kuhnian sense) probably ever existed, it is very difficult to assess if the "intra-disciplinary advancement" is actually different between psychology and physics, chemistry and biology. One empirical study confirms this hypothesis which comes from Simonton's study (2002, p.355), who reanalyzed the theories-to-laws ratio collected by Roeckelein (1997) and showed how this ratio declines as the years pass in physics or chemistry, but rises in psychology, supporting its "softness".

Finally, addressing the question that started this section, psychology appears to be different from the so-called "harder" sciences. It seems to still dwell in a pre-paradigmatic stage (Kuhn, 1970), in which conflicts between rival schools hamper the development of an original research programme (Lakatos, Worrall \& Currie, 1979). This condition has already been "assessed" by many (e.g. Kuhn, 1970; Warren, 1971; Briskman, 1972; Balietti et al., 2015; Melchert, 2016; Goldfried, 2018).

\section{Second critical aspect: is the empirical evidence collected over one hundred years not enough} to declare psychology as a science?

The current work aimed at underlining the theoretical precariousness of psychology, not at undermining its scientific status or at denying its important discoveries and results. It is not our intention to question the validity, necessity or importance of this discipline. We are not discussing whether or not psychology is a science. Instead, our focus is on its epistemological status and on the way in which it could become a paradigmatic discipline and not a pre-paradigmatic one. As we have a great interest in the matter, we do hope that with a clearer theoretical framework, a lot of scientific issues could be tackled with more success.

Third critical aspect: why should evolutionary theory be more complete than others? How would it be adopted?

Evolutionary psychology has a lot of criticisms. Its major tenets have been questioned, including its testability, some of its fundamental cognitive assumptions like the massive modularity, 


\section{PSYCHOLOGY: A GIANT WITH FEET OF CLAY}

the alleged inconsistency of the notion of EEA (environment of evolutionary adaptation), its potential methodological flaws (disjunction and grain problems), its alleged determinism, reductionism and the underestimation of the environmental influences, as well as the so-called "natural teleology" and the "spandrel” problem (Gould \& Lewontin, 1979; Davies, Fetzer \& Foster, 1995; Panksepp \& Panksepp, 2000; Fodor, 2001; Lloyd \& Feldman, 2002; Gannon, 2002; Franks, 2005; Buller, 2006; Richardson, 2007; Hamilton, 2008; Machery, 2008; Rose \& Rose, 2010; Bolhuis, Brown, Richardson, \& Laland, 2011; Ward, 2012; Peters, 2013). However, many of these criticisms seem to be inconsistent due to theoretical misconceptions, as suggested by many evolutionary scholars (Buss, Haselton, Shackelford, Bleske, \& Wakefield, 1998; Carruthers, 2003, 2006; Tooby, Cosmides \& Barrett, 2005; Barkow, 2005; Daly \& Wilson, 2005; Hagen, 2005; 2015; Hagen \& Hammerstein, 2005; Delton, Robertson \& Kenrick, 2006; Machery \& Barrett., 2006; Confer et al., 2010; Van Le et al., 2013; Klasios, 2014; Ploeger \& van der Hoort, 2015).

Despite the considerable empirical support collected, which can be summarized in recently edited handbooks of evolutionary psychology (Barrett, 2007; Buss 2015a, 2015b, 2019) and despite the heartfelt claims of unification under its name (e.g. Cosmides, Tooby \& Barkow, 1992; Tooby \& Cosmides, 1992; Buss, 1995; Caporael, 2001;Tooby \& Cosmides, 2007; Dunbar \& Barrett 2007b, Duntley \& Buss, 2008; Badcock, 2012; Carmen et al., 2013), this discipline is not yet a paradigm in the Kuhnian sense ${ }^{13}$ (Glass, Wilson \& Geher, 2012; Burke, 2014).

We believe that evolutionary psychology may represent a compelling meta-theory. Nevertheless, it is more multifaceted than it is sometimes presented. This approach is indeed often mechanically identified with the "EP" or "Santa Barbara School" - led by John Tooby, Leda Cosmides, Steven Pinker, David Buss and Donald Symons - and with its own theories (Barrett et al., 2014). This trend is often referred to as the narrow-sense evolutionary psychologists (Mameli, 2007)

13 i.e. an acknowledged and shared major theory and methodology around which minor sub-theories "orbit" (Kuhn, 1970) 


\section{PSYCHOLOGY: A GIANT WITH FEET OF CLAY}

However, within evolutionary psychology, different theories have been proposed, aligned to a core-idea that however results in dramatically different assumptions and implications, a tendency that may referred to as the broad sense evolutionary psychology (Mameli, 2007). To testify this pluralism, it is worth noting that some leading evolutionary scholars question the computational postulation, the massive modularity hypothesis and the notion of EEA itself, concepts upon which the "Santa Barbara School" has been built (Dunbar \& Barrett, 2007a, 2007b; Stephen, 2014; Barrett et al., 2014; Barrett, Pollet \& Stulp, 2015; Stulp, Pollet \& Barrett 2015). They firmly believe in the evolutionary framework, but they have a somewhat greater consideration of the environmental influences. For example, in a recent study, Tomasello (2019) suggested from an evolutionary perspective that what makes human unique is primarily related to cultural and ontogenetic processes. As regards for the computational criticisms, there is a growing interest in the e-cognition or distributed cognition (e.g. Barrett, 2011).

Setting aside the specific controversies, what we want to highlight is that evolutionary psychology must not be identified as a monolithic school, rather as a core-idea (“our mind and behavior are significantly shaped by our phylogenetic history") that can be variously addressed. What is fiercely debated concerns specific theories and methodologies: almost no-one would deny that we are animals biologically designed to survive and reproduce. ${ }^{14}$ Most of the critics of evolutionary psychology recognize that its core principle is credible (Hagen, 2015).

However, "the contested nature of evolutionary psychology lies not in our status as evolved beings, but in the extent to which evolutionary ideas add value to studies of human behavior, and the rigor with which these ideas are tested" (Barrett, Pollet \& Stulp, 2014, p. 1). Fodor (2001) advised in this regard that no scientific field, even if logically intriguing, could be valid a priori; the only legitimate criterion is the empirical evidence (a posteriori). He argues (Fodor, 2001, p.83) that there is no pure logical reason constraining the mind and brain to follow the same evolutionary

14 Such statements must be interpreted with caution: the biological design does not imply a reductionistic view of the mind and the main evolutionary aim (reproduction) must be intended not in an overly intuitive manner (Pinker, 1997). 


\section{PSYCHOLOGY: A GIANT WITH FEET OF CLAY}

processes which designed the other organs of the body. Similarly, Fodor goes on, there is no necessary link between "lunar geography" and "cellular mitosis", even if both can be claimed as scientific phenomenon. We find this argument logically consistent but pragmatically inconsistent. Adopting an "Occam's razor" reasoning, we object that there seems to be a far greater "epistemological distance" between lunar geography ${ }^{15}$ and cellular mitosis than the one occurring between the mind-brain system and the rest of the body.

Despite its limitations, evolutionary psychology's global theoretical consistency (which cannot determine its scientific success alone anyway) cannot be ignored (Wilson, 1999). It is linked directly to biology, through which it can be connected to the other "hard" sciences. It is compatible with - and somewhat built on - neuro-cognitivism, and finally it is consistent with other psychological sub-disciplines (e.g. developmental, social, personality and psychopathology) and with other disciplines and sciences, like anthropology (Barrett, 2007; Buss 2015a, 2015b).

A great unresolved issue stands in our way to a theoretical and practical resolution. What about the other "schools of thought"? What about psychoanalysis, Gestalt, systemic, humanistic theory and positive psychology (just to note a few...)? Can they co-exist with evolutionary psychology? Can they maintain their identity? If evolutionary psychology proves itself as a metatheory, will they be "cannibalized"16? The matter is the most important; here probably lies the very nature of the problem.

We explain below why evolutionary psychology seems to prove itself as the most allencompassing approach. Historically, every psychological school posited a "drive" or a "aim" at the very heart of the whole psychological functioning. Melchert (2016, p. 488) labeled it as the "first principle". For Freudian psychoanalysis, this has been the fulfilment of a "drive" (Trieb, in Deutsch), for Jung, it was the process of individualization - and similarly, every psychodynamic author has its own name and related theory. The same happens in other schools of thought as well:

15 Upon which soil no trace of life has been found

16 Adopting a colorful metaphor by E.O Wilson, quoted in Buss (2019, p.39) 


\section{PSYCHOLOGY: A GIANT WITH FEET OF CLAY}

systemic theory, for example, posits that an individual cannot be separated from his familiar context, which is in turn seeking homeostasis. Rogers, often regarded as the "father" of humanistic theory, stated that every individual ultimately seeks self-actualization. This is a rough and simplistic summary, since is not our intention to make a list of all the different "first principles" by different schools. What we want to stress here is that every psychological school posits universal and inborn tendencies in every individual, which are obviously shaped by the environment in which they unfold. This first principles are universal and inborn tendencies, axioms through which all the theoretical and practical corollaries of the given school develop. Without the fulfilment of the drive, there would be no place in Freudian psychoanalysis for "higher" theories (e.g. dream interpretation, transference, psychosexual development, Oedipus complex, Eros and Thanatos etc.), or specific techniques (e.g. interpretation, confrontation, working through etc. ) Similarly, in all the other schools, all theory and practice is eventually related to a first principle(s), which is universal and inborn.

We claim that evolutionary psychology is precisely the most compelling theoretical and empirical effort to frame these universal and inborn tendencies (nature). It is also the most compelling approach to frame the environmental influences intervening in shaping these tendencies (nurture). In this regard, this approach could be based on two theoretical foundations, one nested in each other. The first foundation (nature) seems to clearly be the process of natural selection itself, which poses evolutionary psychology directly in connection with evolutionary biology. The natural selection chooses which components are part of human (and non-human) innateness. There are some controversies about the actual "unit" upon which natural selection acts, but one of the most popular and widely accepted theory today is the gene-centered view of evolution; commonly known as the "selfish gene" theory by Richard Dawkins (Dawkins, 2016). According to Dawkins (and to many biologists that endorse this theory) the selection process does not act on individual organisms or species, rather, it acts on genes. The word "gene" is so important that it must be clearly defined. 


\section{PSYCHOLOGY: A GIANT WITH FEET OF CLAY}

As explicitly stated by Dawkins, the word "gene" is used "in a special sense, tailored to evolution rather than embryology" (...) "A gene is defined as any portion of chromosomal material that potentially lasts for enough generations to serve as a unit of natural selection" (Dawkins, 2016, p.754). Epigenetic variations are comprehended as well, because it is demonstrated that they are hereditable and can be selected in the evolution process (e.g. Del Giudice, 2018). Genes are expressed in phenotypes, but the latter are merely genes' "vehicles". To summarize, evolutionary speaking, it is almost all about genes trying to replicate themselves to become "immortal"17. Complex phenomena like intra-genomic conflict and inclusive-fitness theory find their natural explanation in the Dawkins theory ${ }^{18}$. Of course, the gene-centered view of evolution view has been criticized (e.g. Gould, 1997). Furthermore, complementary and partially different explications have been proposed, like the multilevel selection theory (e.g. Nowak,Tarnita \& Wilson, 2010) which has been harshly criticized by a paper signed by 137 biologists (Abbott et al., 2011). Even if the controversies are far from dissolving, the consensus on the gene-centered view of evolution seems the mainstream theory in the contemporary evolutionary biology, so we will stick with it.

However, a naive application of the "selfish gene" theory to human mind and behavior to frame our "innateness" would lead us to unforgivable mistakes. Thanks to the "seed bank paradox", we can easily grasp the conceptual gap between a naive application of the "selfish gene" theory in psychology and the actual evolutionary process that seems to be in play. For example, if the ultimate goal of an individual is to spread their genes, one could assume (naive application), that the males living in our contemporary society should feel the urge to donate their sperm to a seed bank in order to spread their genes at a dramatically higher rate than the one achievable through simple mating. Of course, this does not happen. The answer to this paradox, Steven Pinker (1997, p.44) wrote is that "Sexual desire is not people's strategy to propagate their genes. It's people's

17 Dawkins himself noted (2016, p.13) that "immortal gene" would had been probably a better title than "selfish gene".

18 These complicated processes are here only mentioned for the sake of brevity. The reader may find further details elsewhere (e.g. Dawkins, 2016) 


\section{PSYCHOLOGY: A GIANT WITH FEET OF CLAY}

strategy to attain the pleasures of sex, and the pleasures of sex are the genes' strategy to propagate themselves." In other words, evolution selected the genes that code for sexual lust, that in turn was a "genes' strategy to propagate themselves". It is the lust, and not a cumbersome psychological mechanism such as the "urge to donate to seed bank" 19 that human beings want to experience. A first important divisor must therefore be drawn between the behaviors' "aim" and genes' "aim". ${ }^{20}$ Behaviors are shaped by genes' "perspective" 21 , but they cannot completely be reduced to them. Here, the second foundation of evolutionary psychology is relevant; what makes our human mind and behavior unique (Tomasello, 1999, 2019). What shaped the human specific psychology in our environment of evolutionary adaptation? The social brain hypothesis, popularized by the British scholar Robin Dunbar (1998, 2009) seems to successfully answer this question. Along with other fundamental adaptations (e.g. problems of survival, problems of sex and mating and problems of parenting and kinship), our Homo Sapiens species seems to distinguish itself due to the importance that the social environment has as a selective pressure to shape our psychological functioning (Dunbar 1998, 2009). ${ }^{22}$ We are, in Tomasello's words (2014), an "ultra-social" animal, the most socially competent species on the planet. We can co-operate in complex ways, "read" other "intentions" (what is often called as "theory of mind"), communicate through a public language, share our attention, etcetera (Tomasello, 1999, 2009). What is crucial here is that our social competence is ultimately permitted by our biological functioning. In a nutshell, we are naturally selected to be cultural. At the same time, our cultural life has a biological impact on us; we are culturally shaped in our nature.

This evolutionary explanation seems to make sense to our extraordinary sensitivity to social

19 The "seed bank" is a very recent cultural introduction and could not be targeted by the genes in so little evolutionary period to develop a psychological mechanism.

20 The word "aim" is used in a deliberately metaphorically fashion, we do not imply teleology for genes.

21 It is absolutely necessary to stress the fact that we are adopting again metaphorical language. Genes actually do not "reason", "plan" or "make strategies", but we could easily grasp conceptually their "behavior" through these mentalistic metaphors.

22 Of course mating, parenting and kinship are social processes themselves, but they are more common in the animal kingdom than the specific Homo Sapiens' social competence, which seems to have being triggered by group living. It is likely that this competence has influenced the process of mating, parenting and kinship, according to a circular causality process. 


\section{PSYCHOLOGY: A GIANT WITH FEET OF CLAY}

signals and to our vulnerability to mental disorders, which characterize themselves very often as an impairment in "social participation" (APA, 2013).

All that being said, evolutionary psychology really seems to prove itself as a compelling meta-theory. It fully accounts both for our innate and universal nature and for the crucial role of our social environment. It can explain both our universal nature and our personal individuality, because it accounts for our high plasticity to our environment, since we are biologically "wired" to collect environmental signals (which in turn can influence our biology). Eventually, it explains why we are so vulnerable to mental disorders. The study of the power of the gene-relatedness in our behavior is now largely attested (e.g. Buss, 2019). More importantly, the "innateness" of evolutionary psychology is biologically and empirically based, it is not drawn from speculation or from clinical observations. At the same time, the social brain hypothesis is in harmony with the clinical observations made by systemic, Gestaltic, and intersubjective schools (just to note a few...). It furthermore explains, along with other complex psychological mechanisms (e.g. Del Giudice, 2018) our abnormal functioning. ${ }^{23}$. In another words, evolutionary psychology really seems to be the most complete and multifaceted approach to comprehend human (and non-human) psychological functioning.

\section{Conclusion}

An analysis of "core-concepts" in psychology (showing unsatisfactory and discordant definitions) and a comparison to "harder" sciences (physics, physics, chemistry and biology) appeared to demonstrate the "soft" nature of psychology and its pre-paradigmatic condition. Evolutionary psychology has been suggested to be the most compelling candidate to possibly overcome this epistemological impasse.

Obviously, there are many limitations to the considerations we proposed here. First, the empirical papers on which we have based our epistemological comparison are not numerous, and

23 Finally, integrative attempts have been made with psychoanalysis as well (e.g. Nesse, 1990; Walters, 1994; Migon e \& Liotti, 1998; Marcaggi \& Guénolé, 2018) 


\section{PSYCHOLOGY: A GIANT WITH FEET OF CLAY}

they should be replicated in more recent times (especially the papers about the "historical trends" in psychology, which also considered the schools in a "monolithic fashion"). Furthermore, someone could more generally question the empirical validity of these analyses from a methodological point of view. In addition, the selection of the sample of introductory books and the "core-constructs" could be questioned as somewhat arbitrary. Finally, the claim of unification under the name of evolutionary could be seen as ideological.

Nonetheless, we believe that our conclusions and main arguments remain robust. Even if the "empirical" papers about conceptual issues are not so numerous, we do believe that they are persuasive enough. This does by any means intend to devalue the theoretical reasoning per se, rather, rooting theory on an empirical ground. In other respects, despite its limitations, the analysis of introductory textbooks seems to capture an intuitive "picture" of the "core" of a science, and the constructs we have analyzed could be easily seen as "pillars" of psychology by many researchers. Furthermore, it would be impossible to conduct an analysis on an uncontroversial list of constructs, because, according to our knowledge, such a list simply does not exist. Finally, the motives we have brought into discussion to "elect" evolutionary psychology as the most compelling metatheory are reasonable, nor totaling or orthodox.

The theoretical chaos affecting psychology is not news (James, 1894; Heidbreder, 1933; Cronbach, 1957; Miller, 1985), however, most unification claims have been made in an argumentative fashion and have focused on methodological, philosophical and conceptual issues. On the other hand, many studies have been conducted to prove that psychology is more chaotic and "softer" than other sciences, or to assess the prominence of its "school of thoughts". None of these studies, however, have directly made a claim in the unification issue. This article wants to be a bridge between these two respectful "traditions" to make a theoretical claim on an empirical ground.

Overcoming a pre-paradigmatic condition with the aid of evolutionary psychology is in 


\section{PSYCHOLOGY: A GIANT WITH FEET OF CLAY}

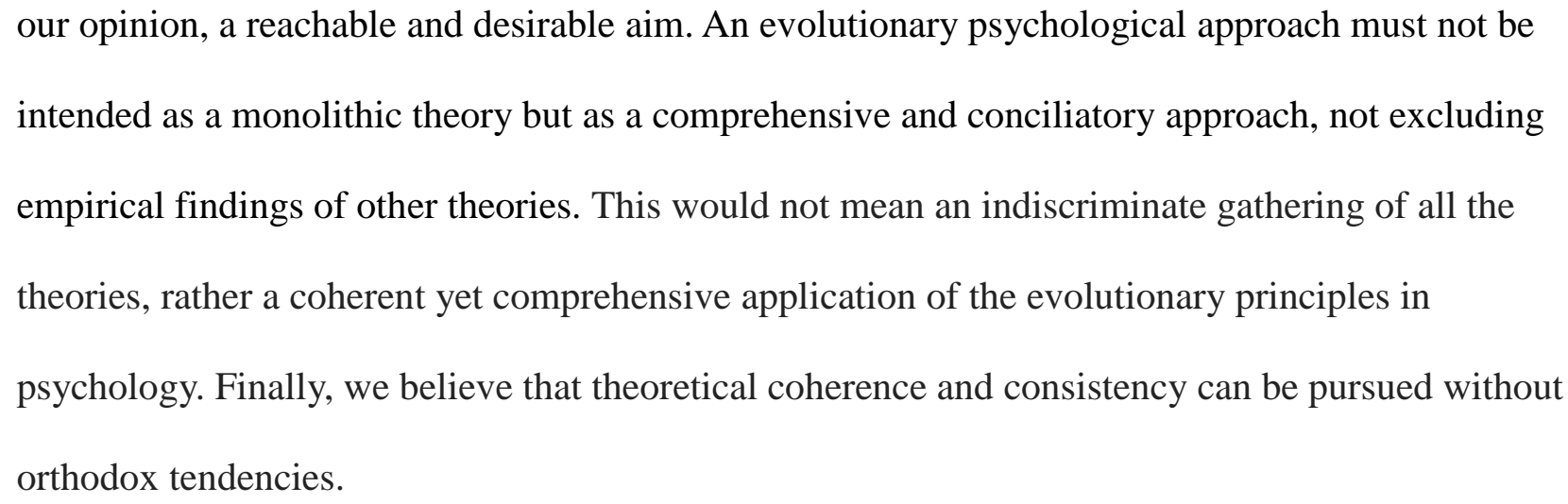




\section{Appendix A - TABLES}

\section{TABLE A1. Definitions of psychology, mind \& behavior}

Behavior is / refers to

$\boldsymbol{X}$
Clarke-Stewart \& p.4.

Psychology is the Mind is scientific study of

Mind and behavior $\quad \boldsymbol{X}$

Roy 2012

Psychology, $9^{\text {th }}$

edition

Cacioppo \& Freberg., Mind and behavior 2013 p.5

\section{Discovering}

psychology: The

science of mind

Ciccarelli \& White, Mind and behavior 2018 p.44

Psychology

Feist \& Rosenberg, thought and 2012 behavior p.5

Psychology:

Perspectives and

Connections.

Grison, Heatherton \& Mind and behavior $\quad \boldsymbol{X}$ Gazzaniga, $2017 \quad$ p.5

Psychology in your life

Hockenbury, Nolan

Mind and behavior

\& Hockenbury, 2015 and brain processes p.2

Psychology (7th ed.)

Lilienfeld, Lynn, Namy \& Woolf, 2014

mind, brain, and behavior

Psychology: From p.35
X
The brain and its activities, including thought, emotion, and behaviour.

p.5

all the internal, covert (hidden) activity such as thinking, feeling, and remembering p. 44

Brain and behaviour p. 5 any action that we can observe p. 5

all of our outward or overt actions and reactions, such as talking, facial expressions, and movement p. 44 $\boldsymbol{X}$

all of our actions that result from sensing and interpreting information p.5

X

X X inquiry to 
understanding (3rd

ed.)

Myers \& DeWall, $\quad$ Mental processes 2015

Psychology (11th ed.) and behavior p. 5 Wegner \& Nock, $\quad$ p. 2 2014

Psychology (3rd ed.)

VandenBos, 2015 behavior

APA dictionary of psychology, second edition

Weiten, 2013

Psychology: Themes and variations, 9th edition internal, subjective experiences we infer from behaviorsensations, perceptions, dreams, thoughts, beliefs, and feelings.

p.5

Schacter, Gilbert, mind and behavior the mind and p. 860

the private inner experience of perceptions, thoughts, memories, and feelings

p. 2

broadly, all intellectual and

psychological phenomena of an organism, encompassing motivational, affective, behavioral, perceptual, and cognitive systems; that is, the organized totality of an organism's mental and psychic processes and the structural and functional cognitive components on which they depend.

(...) p.654

behavior and the $\boldsymbol{X}$ X physiological and cognitive processes that underlie it p. 2 anything an organism does - any action we can observe and record p.5

observable actions of human beings and nonhuman animals p. 2

an organism's activities in response to external or internal stimuli p. 112 
PSYCHOLOGY: A GIANT WITH FEET OF CLAY

1
Zimbardo, Johnson \& $\quad$ behavior and mental $\quad \boldsymbol{X} \quad \boldsymbol{X}$

McCann, $2017 \quad$ processes.

Psychology: Core

$$
\text { p. } 2
$$

\section{Note:}

1. $\operatorname{sign} X$ when the definition has been found missing

2. in some tables, definitions have logic inconsistency. These inconsistencies (i.e. tautologies or equivalences) are explained and highlighted in grey

3. when the original formulators have been explicitly cited by the authors, they have been mentioned in the box and in the references

4. specific comments have been made in italics (e.g. subdivision of memory in long term memory and short-term memory, etc.)

5. the pages on which the definitions are presented are listed below the definitions. 
PSYCHOLOGY: A GIANT WITH FEET OF CLAY

TABLE A2. Definitions of attention, consciousness \& cognition

(selective) Attention

Authors

Bernstein et al., 2012

Psychology, $9^{\text {th }}$ edition

Discovering

psychology: The

science of mind

Ciccarelli \& White, $\quad \boldsymbol{X}$ 2018

Psychology

Feist \& Rosenberg, 2012

Psychology:

Perspectives and

Connections.

$$
\text { p.184 }
$$

$X$

2013

$\begin{array}{ll} & \\ \begin{array}{l}\text { Feist \& Rosenberg, } \\ 2012\end{array} & \begin{array}{l}\text { the limited capacty to } \\ \text { process information } \\ \text { that is under conscious } \\ \text { control. }\end{array} \\ \begin{array}{ll}\text { Psychology: } & \text { Styles, 2006) } \\ \text { Perspectives and } & \text { ponnections. }\end{array}\end{array}$

Consciousness

Tautological:

Awareness of external

stimuli and one's own

mental activity.

(Metzinger, 2000;

Zeman, 2001)

p.331

Grison et al., $2017 \quad \boldsymbol{X}$

Psychology in your

life

Tautological:

A state of awareness. p.236

\section{Tautological: a} person's awareness of everything that is going on around him or her at any given time.(Farthing, 1992)

p. 178

Tautological: an awareness of one's surround- ings and of what's in one's mind at a given moment; includes aspects of being awake and aware.

p. 226

Tautological: The combination of a person's subjective experience of the external world and the person's mental activity; this
Internal mental processes including information processing, thinking, reasoning, and problem solving.

p.454

\section{Considered as equal to thinking}

mental activity that goes on in the brain when a person is organizing and attempting to understand information and communicating information to others. p.306

mental processes involved in acquiring, processing, and storing knowledge.

p.364 
combination results

from brain activity.

p.79

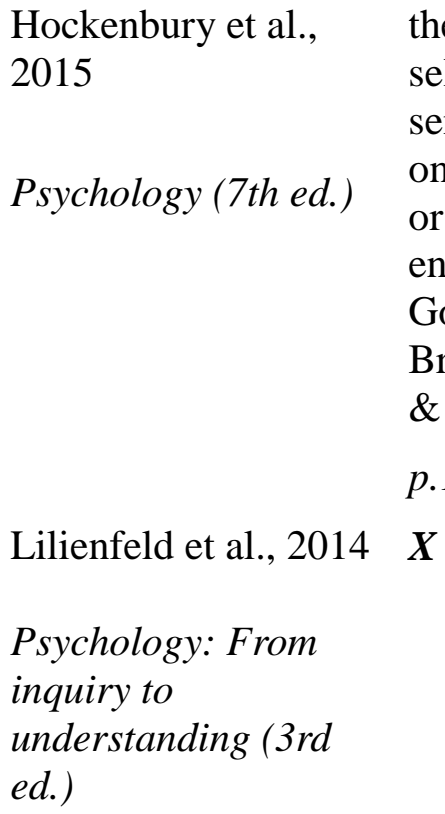

the capacity to selectively focus senses and awareness on particular stimuli or aspects of the environment (Chun, Golomb \& Turk Brown, 2011; Posner \& Rothbart, 2007) p.135

\section{$\boldsymbol{X}$}

(a)

Myers \& DeWall 2015

Psychology (11th ed.)

the focusing of conscious awareness on a particular stimulus. p.96

Schacter et al., 2014 perceiving only what's

Psychology (3rd ed.) you

p.135

VandenBos, 2015

APA dictionary of psychology, second edition

a state in which cognitive resources are fo cused on certain aspects of the environment rather than on others and the central nervous system is in a state of readiness to respond to stimuli. p. 87

\section{Tautological:}

Personal awareness of mental activities, internal sensations, and the external environment

p. 135

Tautological:
our subjective
experience of the
world, our bodies, and
our mental
perspectives
p. 200

X

\section{Considered as equal to thinking}

the term psychologists use to describe the mental processes involved in different aspects of thinking p.61

all the mental activities associated with thinking, knowing, remembering, and communicating. p.357 $\boldsymbol{X}$

A person's subjective experience of the world and the mind. p. 178

Tautological: 1 . the state of being conscious. 2. an organism's awareness of something either internal or external to itself. p. 236

all forms of knowing and awareness, such as perceiving, conceiving, remembering, reasoning, judging, imagining, and problem solving. p.201

Weiten, 2013

focusing awareness on

refers to the mental 
PSYCHOLOGY: A GIANT WITH FEET OF CLAY

a narrowed range of

Psychology: Themes and variations, 9 th edition stimuli or events. p.275

Zimbardo et al., 2017 a feature that makes one item stand out Psychology: Core among others in concepts (8th ed.) consciousness p.290 awareness of internal and external stimuli. p.184 processes involved in acquiring knowledge p.14 // refers broadly to mental processes or thinking p.314

The brain process information processing that creates our mental in the brain representation of the world and our current p.190

\section{Note:}

1. sign $\mathbf{X}$ when the definition has been found missing

2. in some tables, definitions have logic inconsistency. These inconsistencies (i.e. tautologies or equivalences) are explained and highlighted in grey

3. when the original formulators have been explicitly cited by the authors, they have been mentioned in the box and in the references

4. specific comments have been made in italics (e.g. subdivision of memory in long term memory and short-term memory, etc.)

5. the pages on which the definitions are presented are listed below the definitions.

Attention is as multifaceted construct rather than a single concept. Many components have been proposed: selective attention (subdivided in feature-based, object-based, space-based), sustained attention, executive attention... In order not to broaden uncontrollably, our analysis focused on the concept of selective attention alone. 
PSYCHOLOGY: A GIANT WITH FEET OF CLAY

\section{TABLE A3. Definitions of decision-making, intelligence \& language}

Authors
Bernstein et al., $2012 \quad X$
Psychology, $9^{\text {th }}$
edition


Cacioppo \& Freberg, $\quad X$
2013
Discovering
psychology: The
science of mind

\author{
Intelligence \\ cognitive ability: \\ the capacity to reason, \\ remember, \\ understand, solve \\ problems, and make \\ decisions
}

p.373

//

Personal attributes that center around skill at information processing, problem solving, and adapting to new or changing environments

p.374

The ability to understand complex ideas, adapt effectively to the environment, learn from experience, engage in reasoning, and overcome obstacles. (Neisser et al., 1996, p. 77)

p.489

$\begin{array}{ll}\begin{array}{l}\text { Ciccarelli \& White, } \\ 2018\end{array} & \begin{array}{l}\text { process of cognition } \\ \text { that involves } \\ \text { identifying, } \\ \text { evaluating, and } \\ \text { choosing among } \\ \text { several alternatives. } \\ \text { Psychology }\end{array} \\ & \text { p.311 }\end{array}$

Feist \& Rosenberg, $\quad \boldsymbol{X}$ 2012
The ability to learn from one's experiences, acquire knowledge, and use resources effectively in adapting to new situations or solving prob- lems (Sternberg \& Kaufman, 1998; Wechsler, 1975)

p.311

a set of cognitive skills that includes
Language

Symbols and a set of rules for combining them that provide a vehicle for communication.

p.315

A system for communicating thoughts and feelings using arbitrary signals. p. 478

a system for combining symbols (such as words) so that an unlimited num- ber of meaningful statements can be made for the purpose of communicating with others. p.338

a communication system specific to 
Psychology:

Perspectives and

Connections.

Grison et al., 2017

attempting to select the best alternative

Psychology in your life among several options.

p.278

Hockenbury et al., $\quad \boldsymbol{X}$
2015

Psychology (7thed.)

$\begin{array}{ll}\text { Lilienfeld et al., 2014 } & \begin{array}{l}\text { the process of } \\ \text { selecting among a set } \\ \text { of possible } \\ \text { alternatives }\end{array} \\ \begin{array}{l}\text { Psychology: From } \\ \text { inquiry to }\end{array} & \begin{array}{l}\text { understanding (3rd } \\ \text { ed.) }\end{array}\end{array}$

abstract thinking, reasoning, problem solving, and the ability to acquire knowledge.

p.387

The ability to use knowledge to reason, make decisions, make sense of events, solve problems, understand complex ideas, learn quickly, and adapt to environmental challenges

p.287

the global capacity to think rationally, act purposefully, and deal effectively with the environment

(Wechsler, 1944, 1977)

p. 290

Homo sapiens; it is open and symbolic, has rules of grammar, and allows its users to express abstract and distant ideas.

(Bickerton, 1995)

p.349

\section{X}

A system for combining arbitrary symbols to produce an infinite number of meaningful statements.

p. 284

largely arbitrary system of communication that combines symbols (such as words and gestural signs) in rulebased ways to create meaning

p.330

the mental potential to learn from experience, solve problems, and use knowledge to adapt to new situations. p.386 our spoken, written, or signed words and the ways we combine them to communicate meaning.

p. 370 
PSYCHOLOGY: A GIANT WITH FEET OF CLAY

\author{
Schacter et al., $2014 \quad X$ \\ Psychology (3rd ed.)
}

VandenBos, 2015

APA dictionary of psychology, second edition

Weiten, 2013

Psychology: Themes and variations, 9th edition

\author{
Zimbardo et al., $2017 \quad X$ \\ Psychology: Core \\ concepts (8th ed.)
}

\section{Note:}

1. sign $\mathbf{X}$ when the definition has been found missing equivalences) are explained and highlighted in grey mentioned in the box and in the references and short-term memory, etc.) the cognitive process of choosing between two or more alternatives, ranging from the relatively clear cut (e.g., ordering a meal at a restaurant) to the complex (e.g., selecting a mate). p. 286

the ability to direct one's thinking, adapt to one's circumstances, and learn from one's experiences

(Gottfredson, 1997) p.396

the ability to derive information, learn from experience, adapt to the environment, understand, and correctly utilize thought and reason. p.548 evaluating alternatives and making choices among them. p.333

\section{X}

consists of symbols that convey mean- ing, plus rules for combining those symbols, that can be used to generate an infinite variety of messages

p.314

is the mental capacity our ability to to acquire knowledge, communicate through reason, and solve spoken and written problems effecively words and gesture
p.207

2. in some tables, definitions have logic inconsistency. These inconsistencies (i.e. tautologies or

3. when the original formulators have been explicitly cited by the authors, they have been

4. specific comments have been made in italics (e.g. subdivision of memory in long term memory

5. the pages on which the definitions are presented are listed below the definitions. 


\section{TABLE A4 Definitions of learning, memory \& perception}

$\quad$ Authors
Bernstein et al.,
2012
Psychology, $9^{\text {th }}$
edition

Learning

The modification through experience of preexisting behavior and understanding p.197
Memory $X$

The ability to retain knowledge. p.399 capacity for

Discovering psychology: The science of mind

Ciccarelli \& White, 2018

Psychology

Feist \& Rosenberg, 2012

Psychology:

Perspectives and Connections.

Grison et al., 2017 Psychology in your life any relatively permanent change in behavior brought about by experience or practice.

p. 218 enduring changes in behavior that occur with experience.

p.306

a change in behavior, resulting from experience. p.197 information from an active system that receives information from the senses, puts that information into a usable form, and organizes it as it stores it away, and then retrieves the storage.

(adapted from Baddeley, 1996, 2003).

\section{p.264}

the ability to store and use information.

p. 270

the method by which the sensations experienced at any given moment are interpreted and organized in some meaningful fashion. p.160

the act of organizing and interpreting sensory experience p. 125

The processing, organization, and interpretation of sensory signals in the brain; these processes 
retrieval.

p.233

Hockenbury et al.,
2015
Psychology (7th ed.)

Lilienfeld et al., 2014

Psychology: From

inquiry to

understanding (3rd

ed.)

Myers \& DeWall, 2015

Psychology (11th ed.)

A process that produces a relatively enduring change in behavior or knowledge as a result of past experience.

\section{p.183}

change in an organism's behavior or thought as a result of experience

p. 236

the process of acquiring through experience new information or behaviors.

p.280

Schacter et al., 2014 involves the acquisition of new

Psychology (3rd ed.) knowledge, skills, or responses from experience that results in a relatively permanent change in the state of the learner p.266

VandenBos, 2015

APA dictionary of psychology, second edition the acquisition of novel information, behaviors, or abilities after practice, observation, or other experiences, as evidenced by change in behavior, knowledge, or brain function retention of

information over time

p. 276

The persistence of learning over time through the encoding, storage, and retrieval of information.

p.318

The ability to store and retrieve information over time. p.222

the ability to retain information or a representation of past experience, based on the mental processes of learning or encoding, retention across some interval of time, and retrieval or reactivation of the memory. result in an internal neural representation of the physical stimulus.

p.157

The process of integrating, organizing, and interpreting sensations.

p. 86

The brain's interpretation of raw sensory inputs p.156

the process of organizing and interpreting sensory information, enabling us to recognize meaningful objects and events.

p.230

The organization, identification and interpretation of a sensation in order to form a mental representation.

p.130

the process or result of becoming aware of objects, relationships, and events by means of the senses, which includes such activities as recognizing, observing, and discriminating. These activities enable organisms to organize 
PSYCHOLOGY: A GIANT WITH FEET OF CLAY
p. 594
p.636

is any relatively durable change in

\section{X}

behavior or

knowledge that is due

to experience

p. 230

$\begin{array}{ll}\text { Zimbardo et al., } & \begin{array}{l}\text { a process through } \\ \text { which experience } \\ \text { produces a lasting } \\ \text { change in behavior or } \\ \text { mental processes }\end{array} \\ \begin{array}{l}\text { Psychology: Core } \\ \text { concepts (8th ed.) }\end{array} & \text { p.118 }\end{array}$

Human memory is an information processing system that works constructively to encode, store, and retrieve information.

p.154 and interpret the stimuli received into meaningful knowledge and to act in a coordinated manner. p.775

is the selection, organization, and interpretation of sensory input p. 130

mental process that elaborates and assigns meaning to the incoming sensory patterns p.76

\section{Note:}

1. sign $\mathbf{X}$ when the definition has been found missing

2. in some tables, definitions have logic inconsistency. These inconsistencies (i.e. tautologies or equivalences) are explained and highlighted in grey

3. when the original formulators have been explicitly cited by the authors, they have been mentioned in the box and in the references

4. specific comments have been made below in italics (e.g. subdivision of memory in long term memory and short-term memory, etc.)

5. the pages on which the definitions are presented are listed below the definitions.

Like attention, memory is a multifaceted phenomenon rather than a single concept. Sensorial memory, working memory, short-term memory, long term memory (divided in episodic, semantic, explicit or implicit memory), are all dimensions currently studied. In order not to broaden excessively our analysis our focus has been on the general definition of the term. 
PSYCHOLOGY: A GIANT WITH FEET OF CLAY

\section{TABLE A5. Definitions of problem-solving, reasoning \& sensation}

\author{
Authors \\ Bernstein et al., $2012 \quad \boldsymbol{X}$ \\ Psychology, $9^{\text {th }}$ \\ edition
}

Cacioppo \& Freberg, The use of 2013

Discovering

psychology: The

science of mind

Ciccarelli \& White, 2018

Psychology

Feist \& Rosenberg, $\quad \boldsymbol{X}$ 2012

Psychology:

Perspectives and

Connections.

Grison et al., 2017 Finding a way around an obstacle to reach a

Psychology in your life goal.

p. 278 information to meet a specific goal.

(Lovett, 2002)

p.462 that occurs when a goal must be reached by thinking and behaving in certain ways.

p.311

$$
\text { p.278 }
$$

Reasoning

The process by which people generate and evaluate arguments and reach conclusions about them

p.295

$\boldsymbol{X}$

process of cognition $\quad \boldsymbol{X}$

\section{considered as equal to cognition}

mental activity that goes on in the brain when a person is organizing and attempting to understand information and communicating information to others. p.306

the process of drawing $X$ inferences or conclusions from principles and evidence.

(Sternberg, 2006)

p.368

Using information to determine if a conclusion is valid or reasonable.

p. 277
The mental manipulation of representations of information we encounter in our environments p.271 The manipulation of 
PSYCHOLOGY: A GIANT WITH FEET OF CLAY

2015
Psychology (7th ed.)
Lilienfeld et al.,
2014
Psychology: From
inquiry to
understanding (3rd
ed.)

directed toward

attaining a goal that is

mental representations

not readily available.

of information in order

(Novick \& Bassok,

2005)

to draw inferences and

conclusions.

p.273

p.277

generating a cognitive $\quad \boldsymbol{X}$

strategy to accomplish

a goal

p. 326

\section{$X$}

any mental activity or

processing of

information, including

learning, remembering, perceiving, communicating, believing, and deciding p. 320

Myers \& DeWall,
2015
Psychology (11th
ed.)

Schacter et al., $2014 \quad X$

mental activity that

Psychology (3rd ed.)

consists of organizing

information or beliefs

into a series of steps

in order to reach

conclusions.

p.388

VandenBos, 2015

APA dictionary of psychology, second edition

the process by which individuals attempt to overcome difficulties, achieve plans that move them from a

thinking in which logical processes of an inductive or deductive character are used to draw conclusions from facts or premises. desired goal, or reach conclusions through p.837, 838

Weiten, 2013

Psychology: Themes the use of higher mental functions, such as reasoning and creative thinking

active efforts to p. 886
X

X

cognitive behavior in which ideas, images, mental representations, or other hypothetical elements of thought are experienced or manipulated.

p.1084 


\section{PSYCHOLOGY: A GIANT WITH FEET OF CLAY}

$\begin{array}{ll}\begin{array}{l}\text { and variations, 9th } \\ \text { edition }\end{array} & \begin{array}{l}\text { done to achieve a goal } \\ \text { that is not readily } \\ \text { attainable. }\end{array} \\ & \text { p.324 }\end{array}$

Zimbardo et al., $\quad \boldsymbol{X}$ 2017

the ability to compare and evaluate contradictory viewpoints (Baltes \& Staudinger, 1993; King \& Kitchener, 1994)

p. 275
Thinking is a cognitive process in which the brain uses information from the senses, emotions, and memory to create and manipulate mental representations, such as concepts, images, schemas, and scripts.

p.190

\section{Note:}

1. sign $\mathbf{X}$ when the definition has been found missing

2. in some tables, definitions have logic inconsistency. These inconsistencies (i.e. tautologies or equivalences) are explained and highlighted in grey

3. when the original formulators have been explicitly cited by the authors, they have been mentioned in the box and in the references

4. specific comments have been made in italics (e.g. subdivision of memory in long term memory and short-term memory, etc.)

5. the pages on which the definitions are presented are listed below the definitions. 
PSYCHOLOGY: A GIANT WITH FEET OF CLAY

TABLE A5 Definitions of thinking, emotion \& motivation

Authors

Bernstein et al., 2012

Psychology, $9^{\text {th }}$ edition

\section{Discovering} psychology: The science of mind

Cacioppo \& Freberg, 2013

Ciccarelli \& White, 2018

\section{Psychology}

Psychology:

Perspectives and Connections.

Feist \& Rosenberg, 2012

Grison et al., 2017

Psychology in your

\section{Emotion}

Transitory positive or negative experiences that are felt as

happening to the self, are generated in part by cognitive appraisal of a situation, and are accompanied by both learned and innate physical responses.

p.446

A combination of
arousal, physical
sensations, and
subjective feelings
that occurs
spontaneously in
response to
environmental stimuli.
p. 288

A process that arouses, maintains, and guides behavior toward a goal. p.289

The factors that influence the initiation, direction, intensity, and persistence of behavior (Reeve, 1996)

p.413 outside world, and an inner awareness of feelings.

p.413

brief, acute changes in conscious experience and physiology that occur in response to a personally meaningful situation.

$$
\text { p.449 }
$$

Feelings that involve the process by which activities are started, directed, and continued so that physical or psychological needs or wants are met.

(Petri, 1996) p.396 the urge to move toward one's goals p. 426

the process that occurs when special receptors in the sense organs are activated, allowing various forms of outside stimuli to become neural signals in the brain.

p.134

The stimulation of our sense organs by the outer world p. 124

The sense organs' detection of external physical stimulus and 


$\begin{array}{ll}\text { life } & \begin{array}{l}\text { physical responses, } \\ \text { changes in thoughts } \\ \text { and in actions, and } \\ \text { personal evaluation. } \\ p .324\end{array} \\ & \\ \text { Hockenbury et al., } & \begin{array}{l}\text { A complex } \\ \text { psychological state } \\ \text { that involves a } \\ \text { subjective experience, } \\ \text { Psychology (7th ed.) }\end{array} \\ & \begin{array}{l}\text { physiological } \\ \text { response, and a } \\ \text { behavioral or } \\ \text { expressive response. }\end{array} \\ & \begin{array}{l}\text { p.330 } \\ \text { mental state or feeling } \\ \text { associated with our } \\ \text { evaluation of our } \\ \text { experiences }\end{array} \\ \text { Lilienfeld et al., 2014 } & \text { p.442 } \\ \text { Psychology: From } \\ \begin{array}{l}\text { inquiry to } \\ \text { understanding (3rd } \\ \text { ed.) }\end{array}\end{array}$

Myers \& DeWall, 2015

Psychology (11th ed.) physiological arousal,

(2) expressive

behaviors, and (3)

conscious experience.

p.461

Schacter et al., 2014 positive or negative experience that is

Psychology (3rd ed.) associated with a particular pattern of physiological activity.

$$
\text { p.316 }
$$

VandenBos, 2015

APA dictionary of psychology, second edition

complex reaction pattern, involving experiential, behavioral, and physiological strength that energize, direct, and sustain behavior.

p.309

The biological, emotional, cognitive, or social forces that activate and direct behavior.

p.314

The process of detecting a physical stimulus, such as light, sound, heat, or pressure.

p. 86

psychological drives that propel us in a specific direction p.465

detection of physical energy by sense organs, which then send information to the brain

p. 156

a need or desire that energizes and directs behavior.

p. 420

the process by which our sensory receptors and nervous system receive and represent stimulus energies from our environment.

p. 230

the purpose for or psychological cause of an action p.330

simple stimulation of a sense organ

p. 130

disposition, impetus, cause - purpose the impetus that gives purpose or direction to behavior and operates in humans at a conscious or elements, by which an individual attempts to unconscious level the process or experience of perceiving through the senses. p. 962 
PSYCHOLOGY: A GIANT WITH FEET OF CLAY

significant matter or $\quad$ p.670

event.

p.362

Weiten, 2013

Psychology: Themes and variations, 9th edition

involves (1) a subjective conscious

experience (the cognitive component) accompanied by (2) p.388 bodily arousal (the physiological component) and by (3) characteristic overt expressions (the behavioral component p. 411

\begin{tabular}{|c|c|c|}
\hline $\begin{array}{l}\text { Psychology: Core } \\
\text { concepts (8th ed.) }\end{array}$ & $\begin{array}{l}\text { Emotion is a process } \\
\text { involving four main } \\
\text { components: } \\
\text { physiological arousal, } \\
\text { cognitive } \\
\text { interpretation, } \\
\text { subjective } \\
\text { feelings, and } \\
\text { behavioral expression } \\
\text { (...) Emotions are a } \\
\text { special class of } \\
\text { motives that help us } \\
\text { attend to and respond } \\
\text { to important (usually } \\
\text { external) situations } \\
\text { and communicate our } \\
\text { intentions to others }\end{array}$ & $\begin{array}{l}\text { Motives are internal } \\
\text { dispositions to act in } \\
\text { certain ways, although } \\
\text { they can be influenced } \\
\text { by multiple factors, } \\
\text { both internal and } \\
\text { external. } \\
\text { p.324 }\end{array}$ \\
\hline & & \\
\hline
\end{tabular}

involves goal-directed the stimulation of behavior. sense organs p. 130

process by which a stimulated receptor (such as the eyes or ears) creates a pattern of neural messages that represent the stimulus in the brain, giving rise to our initial experience of the stimulus. p.765
Note:
1. sign $\mathbf{X}$ when the definition has been found missing
2. in some tables, definitions have logic inconsistency. These inconsistencies (i.e. tautologies or equivalences) are explained and highlighted in grey
3. when the original formulators have been explicitly cited by the authors, they have been mentioned in the box and in the references
4. specific comments have been made below the header in italics (e.g. subdivision of memory in long term memory and short-term memory, etc.)
5. the pages on which the definitions are presented are listed below the definitions. 


\section{PSYCHOLOGY: A GIANT WITH FEET OF CLAY}

\section{Compliance with Ethical Standards}

Conflict of Interest: Andrea Zagaria declares that he has no conflict of interest. Agata Andò declares that she has no conflict of interest. Alessandro Zennaro declares that he has no conflict of interest.

Ethical approval: This article does not contain any studies with human participants or animals performed by any of the authors.

\section{References}

Abbot, P., Abe, J., Alcock, J., Alizon, S., Alpedrinha, J. A., Andersson, M., ... \& Barton, N. (2011). Inclusive fitness theory and eusociality. Nature, 471(7339), E1-E4.

Anderson, N. (1996). A functional theory of cognition. Mahwah, NJ: Erlbaum.

Anderson, N. (2008). Unified Social Cognition. New York: Psychology Press.

American Psychiatric Association. (2013). Diagnostic and statistical manual of mental disorders (DSM-5®). American Psychiatric Pub.

Badcock, P. B. (2012). Evolutionary systems theory: a unifying meta-theory of psychological science. Review of General Psychology, 16(1), 10-23.

Baddeley, A. D. (1996). Exploring the central executive. Quarterly Journal of Experimental

Baddeley, A. D. (2003). Working memory: Looking back and looking visual forward. Nature Reviews Neuroscience, 4(10), 829-839.

Balietti, S., Mäs, M., \& Helbing, D. (2015). On disciplinary fragmentation and scientific progress. PloS one, 10(3), e0118747.

Baltes, P. B., \& Staudinger, U. M. (1993). The search for a psychology of wisdom. Current Directions in Psychological Science, 2, 75-80.

Barkow, J. H. (Ed.). (2005). Missing the revolution: Darwinism for social scientists. Oxford University Press.

Barrett, L. (2007). Oxford handbook of evolutionary psychology. Oxford University Press, USA.

Barrett, L. (2011). Beyond the brain: How body and environment shape animal and human minds. Princeton University Press.

Barrett, L., Pollet, T. V., \& Stulp, G. (2014). From computers to cultivation: reconceptualizing evolutionary psychology. Frontiers in psychology, 5, 867.

Barrett, L., Pollet, T., \& Stulp, G. (2015). Evolved biocultural beings (who invented computers). Frontiers in psychology, 6, 1047.

Bedau, M. A., \& Humphreys, P. E. (2008). Emergence: Contemporary readings in philosophy and science. MIT press.

Bednekoff, P. A. (2005). Animal behavior in introductory textbooks: consensus on topics, confusion over terms. BioScience, 55(5), 444-448.

Benovsky, J. (2016). Dual- Aspect Monism. Philosophical investigations, 39(4), 335-352.

Bernstein, D., Penner, L., Clarke-Stewart, A., Roy, E. (2012). Psychology, 9th edition. Independence, KY: Cengage.

Bickerton, D. (1995). Language and human behavior. Seattle: University of Washington Press.

Bolhuis, J. J., Brown, G. R., Richardson, R. C., \& Laland, K. N. (2011). Darwin in mind: New opportunities for evolutionary psychology. PLoS biology, 9(7), e1001109.

Briskman, L. B. (1972). Is a Kuhnian analysis applicable to psychology? Science Studies, 2, 87-97. 


\section{PSYCHOLOGY: A GIANT WITH FEET OF CLAY}

Brüne, M. (2015). Textbook of evolutionary psychiatry and psychosomatic medicine: The origins of psychopathology. Oxford University Press.

Buller, D. J. (2006). Adapting minds: Evolutionary psychology and the persistent quest for human nature. MIT press.

Burke, D. (2014). Why isn't everyone an evolutionary psychologist?. Frontiers in psychology,5, 910.

Burman, J. T. (2018). Through the looking-glass: PsycINFO as an historical archive of trends in psychology. History of Psychology, 21(4), 302.

Buss, D. M. (1995). Evolutionary psychology: A new paradigm for psychological science. Psychological inquiry, 6(1), 1-30.

Buss, D. M. (Ed.). (2015a). The handbook of evolutionary psychology, volume 1: foundation (Vol. 1). John Wiley \& Sons.

Buss, D. M. (Ed.). (2015b). The handbook of evolutionary psychology, volume 2: integrations (Vol. 2). John Wiley \& Sons.

Buss, D. (2019). Evolutionary psychology: The new science of the mind. Routledge

Buss, D. M., Haselton, M. G., Shackelford, T. K., Bleske, A. L., \& Wakefield, J. C. (1998). Adaptations, exaptations, and spandrels. American psychologist, 53(5), 533.

Cacioppo, J., \& Freberg, L. (2013). Discovering psychology: The science of mind. Independence, KY: Cengage.

Caporael, L. R. (2001). Evolutionary psychology: Toward a unifying theory and a hybrid science. Annual review of psychology, 52(1), 607-628.

Carmen, R. A., Geher, G., Glass, D. J., Guitar, A. E., Grandis, T. L., Johnsen, L., ... \& Tauber, B. R. (2013). Evolution integrated across all islands of the human behavioral archipelago: All psychology as Evolutionary Psychology. EvoS Journal: The Journal of the Evolutionary Studies Consortium, 5(1), 108-126.

Carruthers, P. (2003). Moderately massive modularity. Royal Institute of Philosophy Supplements, 53, 67-89.

Carruthers, P.(2006) : The Architecture of the Mind: Massive Modularity and the Flexibility of Thought. Oxford : Oxford University Press .

Chun, Marvin M.; Golomb, Julie D.; \& Turk-Browne, Nicholas B. (2011). A taxonomy of external and internal attention. Annual Review Psychology, 62, 2011 73-101

Ciccarelli, S. K., White J.N. (2018). Psychology. Global Edition-Pearson

Cleveland, W. S. (1984). Graphs in scientific publi- cations. American Statistician, 38, 261-269.

Cole, S. (1983). The hierarchy of the sciences?. American Journal of Sociology, 89(1), 111-139.

Cole, S. (1994). Why sociology doesn't make progress like the natural sciences. In Sociological forum (Vol. 9, No. 2, pp. 133-154). Springer Netherlands.

Cole S. (2001) What's wrong with sociology? New Brunswick, NJ: Transacton Publishers.

Colosi, J. (2000). Redefining the" scientific method". The American Biology Teacher, 62(1), 32-40.

Confer, J. C., Easton, J. A., Fleischman, D. S., Goetz, C. D., Lewis, D. M., Perilloux, C., \& Buss, D. M. (2010). Evolutionary psychology: Controversies, questions, prospects, and limitations. American Psychologist, 65(2), 110.

Cosmides, L., Tooby, J. \& Barkow, J. (1992) Evolutionary psychology and conceptual integration. In: The adapted mind: Evolutionary psychology and the generation of culture, ed. J. Barkow, L. Cosmides \& J. Tooby. Oxford University Press. 3 - 15

Costa, R. E., \& Shimp, C. P. (2011). Methods courses and texts in psychology:"textbook science" and "tourist brochures" Journal of Theoretical and Philosophical Psychology, 31(1), 25.

Cronbach, L.J. (1957). The two disciplines of scientific psychology. American Psychologist, 12, $671-684$.

Daly, M., \& Wilson, M. (2005). The 'Cinderella Effect' is no fairy tale. Trends in Cognitive 


\section{PSYCHOLOGY: A GIANT WITH FEET OF CLAY}

Sciences, 9, 507-508. doi:10.1016/j.tics.2005.09.007

Danese, A., Caspi, A., Williams, B., Ambler, A., Sugden, K., Mika, J., ... \& Arseneault, L. (2011). Biological embedding of stress through inflammation processes in childhood. Molecular psychiatry, 16(3), 244.

Davies, P. S., Fetzer, J. H., \& Foster, T. R. (1995). Logical reasoning and domain specificity. Biology and Philosophy, 10(1), 1-37

Dawkins, R. (2016). The selfish gene. Oxford university press.

De Groot, A. D. (1990). Unifying psychology: a European view. New ideas in Psychology, 8(3), 309-320.

Del Giudice, M. (2018). Evolutionary psychopathology: A unified approach. Oxford University Press.

Delton, A. W., Robertson, T. E., \& Kenrick, D. T. (2006). The mating game isn't over: A reply to Buller's critique of the evolutionary psychology of mating. Evolutionary Psychology 4(1), 147470490600400122.

Dunbar, R. I. (1998). The social brain hypothesis. Evolutionary Anthropology: Issues, News, and Reviews: Issues, News, and Reviews, 6(5), 178-190.

Dunbar, R. I. (2009). The social brain hypothesis and its implications for social evolution. Annals of human biology, 36(5), 562-572.

Dunbar, R. I., \& Barrett, L. (2007b). Evolutionary psychology in the round. Oxford handbook of evolutionary psychology, 3-9.

Dunbar, R.I., \& Barrett, L. (2007a). Oxford handbook of evolutionary psychology. Oxford University Press, USA.

Dunn, P. K., Carey, M. D., Farrar, M. B., Richardson, A. M., \& McDonald, C. (2017). Introductory statistics textbooks and the GAISE recommendations. The American Statistician, 71(4), 326-335.

Duntley, J. D., \& Buss, D. M. (2008). Evolutionary psychology is a metatheory for psychology. e.g., Horowitz, 1987; Reese \&Overton, 1972)

Edelman, G. M. (2003). Naturalizing consciousness: A theoretical framework. Proceedings of the National Academy of Sciences, 100(9), 5520-5524.

Edelman, G. Tononi,. G. (2001). A universe of consciousness: How matter becomes imagination.

Fanelli, D. (2010). "Positive" results increase down the hierarchy of the sciences. PloS one, 5(4), e10068.

Fanelli, D., \& Glänzel, W. (2013). Bibliometric evidence for a hierarchy of the sciences. PLoS One, 8(6), e66938.

Farthing, G. W. (1992). The psychology of consciousness. Englewood Cliffs, NJ: Prentice Hall.

Feist, G., \& Rosenberg, E. (2011). Psychology: Perspectives and Connections. New York, NY: McGraw Hill.

Festinger, L. (1954). A theory of social comparison processes. Human relations, 7(2), 117-140.

Ferguson, C. J., Brown, J. M., \& TorresBrown, J. M., \& Torres , A. V. (2018). Education or indoctrination? The accuracy of introductory psychology textbooks in covering controversial topics and urban legends about psychology. Current Psychology, 37(3), 574-582.

Fernald, D. (2007). An emerging science. Psychology: six perspectives. Sage Publications. 1-21

Fodor, J. A. (2001). The mind doesn't work that way: The scope and limits of computational psychology. MIT press.

Franks, B. (2005). The role of 'the environment' in cognitive and evolutionary psychology. Philosophical psychology, 18(1), 59-82.

Friman, P. C., Allen, K. D., Kerwin, M. L., \& Larzelere, R. (1993). Changes in modern psychology: A citation analysis of the Kuhnian displacement thesis. American Psychologist, 48(6), 658.

Frith, C., \& Dolan, R. (1996). The role of the prefrontal cortex in higher cognitive functions. Cognitive brain research, 5(1-2), 175-181.

Gaj, N. (2016). Unity and fragmentation in psychology: The philosophical and methodological 


\section{PSYCHOLOGY: A GIANT WITH FEET OF CLAY}

roots of the discipline. Routledge.

Gannon, L. (2002). A critique of evolutionary psychology. Psychology, Evolution \& Gender, 4(2), 173-218.

Gergen, K. J. (1988). United we fall: A response to Krantz. New ideas in psychology, 6(2), 219-222.

Glass, D. J., Wilson, D. S., \& Geher, G. (2012). Evolutionary training in relation to human affairs is sorely lacking in higher education. EvoS Journal: The journal of the evolutionary studies consortium, 4(2), 16-22.

GlenbergM. (2010). Embodiment as a unifying perspective for psychology. Wiley Interdisciplinary Reviews: Cognitive Science, 1(4), 586-596.

Goldfried, M. R. (2018). Obtaining consensus in psychotherapy: What holds us back?. American Psychologist.

Gottfredson, L. S. (1997). Mainstream science on intelligence: An editorial with 52 signatories, history, and bibliography. Intelligence, 24, 13-23.

Gould, S. J., \& Lewontin, R. C. (1979). The spandrels of San Marco and the Panglossian paradigm: A critique of the adaptationist programme. Proceedings of the Royal Society B: Biological Sciences, 205(1161), 581-598.

Gould, S. J. (1997). Darwinian fundamentalism. New York Review of Books, 44, 34-37.

Griffiths, P. E., \& Stotz, K. (2008). Experimental philosophy of science. Philosophy Compass, 3(3), 507-521.

Griggs, R. A., \& Christopher, A. N. (2016). Who's who in introductory psychology textbooks: A citation analysis redux. Teaching of Psychology, 43(2), 108-119.

Grison, S., Heatherton, T. F., \& Gazzaniga, M. S. (2017). Psychology in your life. New York, NY: Norton.

Habarth, J., Hansell, J., \& Grove, T. (2011). How accurately do introductory psychology textbooks present psychoanalytic theory?. Teaching of Psychology, 38(1), 16-21.

Hagen, E. H. (2005). Controversial issues in evolutionary psychology. The handbook of evolutionary psychology, 145-173.

Hagen, E. H. (2015). Evolutionary psychology and its critics. The handbook of evolutionary psychology, 1-25.

Hagen, E. H., \& Hammerstein, P. (2005). Evolutionary biology and the strategic view of ontogeny: Genetic strategies provide robustness and flexibility in the life course. Research in Human Development, 2 (1-2), 83-97.

Hamilton, R. (2008). The Darwinian cage: evolutionary psychology as moral science. Theory, Culture \& Society, 25(2), 105-125.

Heidbreder, E. (1933). Seven psychologies. London, England: Century/Random House UK. Henriques, G. R. (2003). The Tree of Knowledge System and the theoretical unification of psychology. Review of General Psychology, 7, 150 - 182

Henriques, G. R. (2004). Psychology defined. Journal of Clinical Psychology, 60(12), 1207-1221.

Henriques, G. R. (2011). A New Unified Theory of Psychology. New York: Springer.

Henriques, G. (2017). Achieving a unified clinical science requires a meta-theoretical solution:

Comment on Melchert (2016).

Hockenbury, S. E., Nolan, S. A., \& Hockenbury, D. H. (2015). Psychology (7th ed.). New York, NY: Worth Publishers.

James, W. (1894). Epilogue. Psychology, briefer course (Vol. 14). Harvard University Press. 395401

Janda, L. H., England, K., Lovejoy, D., \& Drury, K. (1998). Attitudes toward psychology relative to other disciplines. Professional Psychology: Research and Practice, 29(2), 140.

Jung, C. G. (1947). Riflessioni teoriche sull'essenza della psiche. La dinamica dell'inconscio, Opere, 8.

Keith, B., \& Ender, M. G. (2004). The sociological core: Conceptual patterns and idiosyncrasies in 


\section{PSYCHOLOGY: A GIANT WITH FEET OF CLAY}

the structure and content of introductory sociology textbooks, 1940-2000. Teaching Sociology, 32(1), 19-36.

Kimble, G. A. (1994). A frame of reference for psychology. American Psychologist, 49(6), 510.

King, P. M., \& Kitchener, K. S. (1994). Developing reflective judgment: Understanding and promoting intellectual growth and critical thinking in adolescents and adults. San Francisco, CA: Jossey-Bass.

Kirschner, S. R. (2006). Psychology and pluralism: Toward the psychological studies. Journal of Theoretical and Philosophical Psychology, 26(1-2), 1.

Kissee, J. L., Isaacson, L. J., \& Miller-Perrin, C. (2014). An analysis of child maltreatment content in introductory psychology textbooks. Journal of Aggression, Maltreatment \& Trauma, 23(3), 215-228.

Klasios, J. (2014). Evolutionary psychology and design reincarnation: A reply to Peters. Theory \& Psychology, 24(1), 124-134.

Koch, S. (1993). "Psychology" or the "psychological studies." American Psychologist, 48, 902904.

Krantz, D. L. (1987). Psychology's search for unity. New Ideas in Psychology, 5(3), 329-339.

Kuhn TS (1970) The structure of scientific revolutions. Chicago: The University of chicago Press.

Kukla, A. (1992). Unification as a goal for psychology. American Psychologist, 47, 1054-1055

Lakatos, I., Worrall, J., \& Currie, G. (1979). The methodology of scientific research programmes: philosophical papers.

Lanius, R. A., Vermetten, E., \& Pain, C. (2010). The impact of early life trauma on health and disease. Cambridge, UK: Cambridge UP.

Lilienfeld, S. O. (2004). Defining psychology: Is it worth the trouble?. Journal of clinical psychology, 60(12), 1249-1253.

Lilienfeld, S. O., Lynn, S. J., Namy, L. L., \& Woolf, N. J. (2014). Psychology: From inquiry to understanding (3rd ed.). Upper Saddle River, NJ: Pearson Education.

Lloyd, E. A., \& Feldman, M. W. (2002). Commentary: Evolutionary psychology: A view from evolutionary biology. Psychological Inquiry, 13(2), 150-156.

Lovett, M. C. (2002). Problem solving. In H. Pashler \& D. Medin (Eds.), Stevens' handbook of experimental psychology: Vol. 2. Memory and cognitive processes (3rd ed., pp. 317-362)., Hoboken, NJ: Wiley.

Machery, E. "Massive modularity and the flexibility of human cognition." Mind \& Language 23, no. 3 (2008): 263-272.

Machery, E. (2016). Experimental philosophy of science. A companion to experimental philosophy, 475-490.

Machery, E. and Barrett, C. 2006: Debunking Adapting Minds. Philosophy of Science, 72, 232-46.

Mameli, M. (2007). Evolution and psychology in philosophical perspective. Oxford handbook of evolutionary psychology, 21-34.

Manza, J., \& Van Schyndel, D. (2000). Still the missing feminist revolution? Inequalities of race, class, and gender in introductory sociology textbooks. American Sociological Review, 65(3), 468475.

Marcaggi, G., \& Guénolé, F. (2018). Freudarwin: Evolutionary thinking as a root of psychoanalysis. Frontiers in psychology, 9.

McDowell, J. M. (1982). Obsolescence of knowledge and career publication profiles: Some evidence of differences among fields in costs of interrupted careers. American Economic Review, 72, 752-768.

McMaster, K., Rague, B., Sambasivam, S., \& Wolthuis, S. L. (2019). Software Concepts Emphasized in Introductory Programming Textbooks. Information Systems Education Journal, 17(5), 4.

McNally, R. J. (1992). Disunity in psychology: Chaos or speciation? American Psychologist, 47(8), 


\section{PSYCHOLOGY: A GIANT WITH FEET OF CLAY}

1054-1054.

Meehl, P. E. (1954). Clinical versus statistical prediction: A theoretical analysis and a review of the evidence. Minneapolis, MN, US: University of Minnesota Press.

Melchert, T. P. (2016). Leaving behind our preparadigmatic past: Professional psychology as a unified clinical science. American Psychologist, 71(6), 486.

Metzinger, T. (2000). Neural correlates of consciousness: Empirical and conceptual questions. MIT press.

Migone, P., \& Liotti, G. (1998). Psychoanalysis and cognitive-evolutionary psychology: an attempt at integration. International journal of psycho-analysis, 79, 1071-1095.

Miller, G. (1985). The constitutive problem of psychology. In S. Koch \& D. E. Leary (Eds.), A century of psychology as science (pp. 40-45). New York: McGraw-Hill.

Miller, R. B. (2001). Scientific vs. clinical-based knowledge in psychology: A concealed moral conflict. American journal of psychotherapy, 55(3), 344-356.

Myers, D. G., \& DeWall, C. N. (2015). Psychology (11th ed.). New York, NY: Worth Publishers.

Neisser, U., Boodoo, G., Bouchard, T. J., Boykin, A. W., Brody, N., Ceci, S. J., et al. (1996). Intelligence: Knowns and unknowns. American Psychologist, 51(2), 77-101.

Nelson, D. J., Kumar, R., \& Ramasamy, S. (2015). Comparing Carbonyl Chemistry in Comprehensive Introductory Organic Chemistry Textbooks. Journal of Chemical Education, 92(7), 1171-1177.

Nesse, R. M. (1990). The evolutionary functions of repression and the ego defenses. Journal of the American Academy of Psychoanalysis, 18(2), 260-285.

Nesse, R. M. (2013). Tinbergen's four questions, organized: A response to Bateson and Laland.Trends in Ecology \& Evolution, 28(12), 681-82.

Nesse, R. M. (2015). Evolutionary psychology and mental health. The handbook of evolutionary psychology, 1-20.

Newell, A. (1994). Unified theories of cognition. Harvard University Press.

Norcross, J. C., Karpiak, C. P., \& Santoro, S. O. (2005). Clinical psychologists across the years: The division of clinical psychology from 1960 to 2003. Journal of clinical psychology, 61(12), 1467-1483.

Novick, Laura R.; \& Bassok, Miriam. (2005). Problem solving. In Keith J. Holyoak \& Robert G. Morrison (Eds.), The Cambridge handbook of thinking and reasoning. New York: Cambridge University Press.

Nowak, M. A., Tarnita, C. E., \& Wilson, E. O. (2010). The evolution of eusociality. Nature, 466(7310), 1057-1062.

Ochsner, K. N., \& Kosslyn, S. M. (2013). Introduction to The Oxford Handbook of Cognitive Neuroscience: Cognitive Neuroscience-Where Are We Now?. The Oxford Handbook of Cognitive Neuroscience, Volume 2: The Cutting Edges, 2, 1.

Panksepp, J., \& Panksepp, J. B. (2000). The seven sins of evolutionary psychology. Evolution and cognition, 6(2), 108-131.

Peters, B. M. (2013). Evolutionary psychology: neglecting neurobiology in defining the mind. Theory \& Psychology, 23(3), 305-322.

Petri, H. (1996). Motivation: Theory, research and application (4th ed.). Belmont, CA: Wadsworth.

Pettersson, E., Anckarsäter, H., Gillberg, C., \& Lichtenstein, P. (2013). Different neurodevelopmental symptoms have a common genetic etiology. Journal of Child Psychology and Psychiatry, 54(12), 1356-1365.

Pettit, M. (2016). Historical time in the age of big data: Cultural psychology, historical change, and the Google Books Ngram Viewer. History of Psychology, 19, 141-153.

Pinker, S. (1997) How the Mind Works. London: Allen Lane/Penguin.

Ploeger, A., \& van der Hoort, B. (2015). Evolutionary psychology as a metatheory for the social sciences: How to gather interdisciplinary evidence for a psychological adaptation. Review of 


\section{PSYCHOLOGY: A GIANT WITH FEET OF CLAY}

General Psychology, 19(3), 381-392.

Popper, K. R. (1972). A realist view of logic, physics, and history. Objective knowledge. Oxford, England: Clarendon Press. p.285-318

Porcelli, P. (2009). Medicina psicosomatica e psicologia clinica: modelli teorici, diagnosi, trattamento. Cortina.

Posner, Michael I. \& Rothbart, Mary K. (2007) Research on attention networks as a model for the integration of psychological science. Annual Review of Psychology, 58, 1-23.

Price DJdS (1970) Citation measures of hard science, soft science, technology, and nonscience. Communication among scientists and engineers. Lexington, MA: Heath Lexington Books, D.C. Heath and Company. 3-22.

Ravinder, H., \& Misra, R. B. (2016). The Treatment Of Six Sigma In Introductory Operations Management Textbooks: Clearing Up The Confusion. American Journal of Business Education.

Reeve, J. M. (1996). Understanding motivation and emotion. Orlando, FL: Harcourt Brace

Richardson, R. C. (2007). Evolutionary psychology as maladapted psychology. MIT press.

Reisberg, D. (Ed.). (2013). The Oxford handbook of cognitive psychology. Oxford University Press.

Robins, R. W., Gosling, S. D., \& Craik, K. H. (1999). An empirical analysis of trends in psychology. American Psychologist, 54(2), 117.

Roeckelein, J. E. (1996). Citation of laws and theories in textbooks across 112 years of psychology. Psychological Reports, 79, 979-998.

Roeckelein, J. E. (1997). Psychology among the sciences: Comparisons of numbers of theories and laws cited in textbooks. Psychological Reports, 80, 131-141.

Rose, H., \& Rose, S. (2010). Alas poor Darwin: Arguments against evolutionary psychology. Random House.

Royce, J. R. (1987). More order than a telephone book? A response to Krantz. New Ideas in Psychology, 5(3), 341-345.

Schacter, D. L., Gilbert, D. T., Wegner, D. M., \& Nock, M. K. (2014). Psychology (3rd ed.). New York, NY: Worth Publishers.

Shin, K. H. (2014). Global Multiculturalism in Undergraduate Sociology Course: An Analysis of Introductory Textbooks in the US. Multicultural Education Review, 6(1), 79-101.

Siegel, D. J. (2012). Pocket Guide to Interpersonal Neurobiology: An Integrative Handbook of the Mind (Norton Series on Interpersonal Neurobiology). WW Norton \& Company.

Siegel, D. J. (2016). Mind: A Journey to the Heart of Being Human (Norton Series on Interpersonal Neurobiology). WW Norton \& Company.

Simonton, D. K. (1990). Psychology, science, and history: An introduction to historiometry. New Haven, CT: Yale University Press.

Simonton, D. K. (2002). Great psychologists and their times: Scientific insights into psychology's history. Washington, DC: American Psychological Association.

Simonton, D. K. (2004). Psychology's status as a scientific discipline: Its empirical placement within an implicit hierarchy of the sciences. Review of General Psychology, 8(1), 59-67.

Simonton, D. K. (2006). Scientific status of disciplines, individuals, and ideas: Empirical analyses of the potential impact of theory. Review of General Psychology, 10(2), 98-112.

Spear, J. H. (2007). Prominent schools or other active specialties? A fresh look at some trends in psychology. Review of General Psychology, 11(4), 363-380.

Staats, A. W. (1991). Unified positivism and unification psychology: Fad or new field?. American Psychologist, 46(9), 899.

Staats, A. W. (1999). Unifying psychology requires new infrastructure, theory, method, and a research agenda. Review of General Psychology, 3(1), 3-13.

Stam, H. J. (2004). Unifying psychology: Epistemological act or disciplinary maneuver?.Journal of Clinical Psychology, 60(12), 1259-1262.

Stephen, I. D. (2014). Putting the theory before the data: is "massive modularity" a necessary 


\section{PSYCHOLOGY: A GIANT WITH FEET OF CLAY}

foundation of evolutionary psychology?. Frontiers in psychology, 5, 1158.

Sternberg, R. J. (2005). Unity in psychology: Possibility or pipedream?. American Psychological Association.

Sternberg, R. J. (2006). Cognitive psychology (4th ed.). Belmont: CA: Thomson- Wadsworth.

Sternberg, R. J., \& Grigorenko, E. L. (2001). Unified psychology.

Sternberg, R. J., \& Kaufman, J. C. (1998). Human abilities. Annual Review of Psychology,

Stotz, K. (2014). Extended evolutionary psychology: the importance of transgenerational developmental plasticity. Frontiers in psychology, 5, 908.

Stulp, G., Pollet, T. V., \& Barrett, L. (2015). The not-always-uniquely-predictive power of an evolutionary approach to understanding our not-so-computational nature. Frontiers in psychology, 6, 419.

Suls, J., \& Fletcher, B. (1983). Social comparison in the social and physical sciences: An archival study. Journal of Personality and Social Psychology, 44, 575-580.

Styles, E. A. (2006). The psychology of attention (2nd ed.). Hove, England: Psychology Press.

Sytsma, J., \& Buckwalter, W. (Eds.). (2016). A companion to experimental philosophy. John Wiley $\&$ Sons.

Tinbergen, N. (1963). On aims and methods of ethology. Zeitschrift für tierpsychologie, 20(4), 410433.

Tomasello, M. (1999). The cultural origins of human cognition. Harvard university press.

Tomasello, M. (2014). The ultra- social animal. European journal of social psychology, 44(3), 187194.

Tomasello, M. (2019). Becoming human: A theory of ontogeny. Belknap Press.

Tononi, G, Sporns, O., \& Edelman, G. M. (1994). A measure for brain complexity: relating functional segregation and integration in the nervous system. Proceedings of the National Academy of Sciences of the United States of America, 91(11), 5033-5037.

Tooby, J. \& Cosmides, L. (1992) The psychological foundations of culture. In: The adapted mind: Evolutionary psychology and the generation of culture, ed. J. H. Barkow, L. Cosmides \& J. Tooby,pp. 19 - 136. Oxford University Press.

Tooby, J., \& Cosmides, L. (2007). Evolutionary psychology, ecological rationality, and the unification of the behavioral sciences. Behavioral and Brain Sciences, 30(1), 42-43.

Tooby, J., Cosmides, L., \& Barrett, H. C. (2005). Resolving the debate on innate ideas. The innate mind: Structure and content, 305-3

Toulmin, S. (1987). On not overunifying psychology: A response to Krantz. New ideas in Psychology, 5, 351--353.

Tracy, J. L., Robins, R. W., \& Gosling, S. D. (2005). Tracking trends in psychological science. In The Life Cycle of Psychological Ideas (pp. 105-130). Springer, Boston, MA.

Van der Kolk, B. A. (2015). The body keeps the score: Brain, mind, and body in the healing of trauma. Penguin Books.

Van Le, Q., Isbell, L. A., Matsumoto, J., Nguyen, M., Hori, E., Maior, R. S., ... \& Nishijo, H. (2013). Pulvinar neurons reveal neurobiological evidence of past selection for rapid detection of snakes. Proceedings of the National Academy of Sciences, 110(47), 19000-19005.

VandenBos, G. R. (2015). APA dictionary of psychology, second edition. American Psychological Association.

Wakefield, J. C. (2014). Wittgenstein's nightmare: why the RDoC grid needs a conceptual dimension. World Psychiatry, 13(1), 38.

Wallace, W. L. (1988). Toward a disciplinary matrix in sociology. Handbook of Sociology. Newbury Park, CA: Sage, 23-76.

Wallach, L., \& Wallach, M. A. (2012). Seven Views of Mind. Psychology Press.

Walters, S. (1994). Algorithms and archetypes: evolutionary psychology and Carl Jung's theory of the collective unconscious. Journal of social and evolutionary systems, 17(3), 287-306. 


\section{PSYCHOLOGY: A GIANT WITH FEET OF CLAY}

Ward, C. (2012). Evolutionary psychology and the problem of neural plasticity. In Philosophy of Behavioral Biology (pp. 235-254). Springer, Dordrecht.

Warne, R. T., Astle, M. C., \& Hill, J. C. (2018). What do undergraduates learn about human intelligence? An analysis of introductory psychology textbooks. Archives of Scientific Psychology, 6(1), 32.

Warren, N. (1971). Is a scientific revolution taking place in psychology? Doubts and reservations. Science Studies, 4, 407-413.

Webster, G. D. (2007). Evolutionary theory in cognitive neuroscience: A 20-year quantitative review of publication trends. Evolutionary Psychology, 5(3), 147470490700500304.

Wechsler, D. (1975). The collected papers of David Wechsler. New York: Academic Press.

Wechsler, David. (1944). The measurement of adult intelligence (3rd ed.). Baltimore:Williams \& Wilkins.

Wechsler, David. (1977). Manual for the Wechsler Intelligence Scale for Children (Rev.). New York: Psychological Corporation.

Weiten, W. (2013). Psychology: Themes and variations, 9th edition. Belmont, CA: Wadworth.

Whaley, A. L., Clay III, W. A., \& Broussard, D. (2017). Cultural Diversity in Introductory Psychology Textbook Selection: The Case for Historically Black Colleges/Universities (HBCUs). Psychology Learning \& Teaching, 16(1), 19-35.

Whitehead III, G. I., Smith, S. H., \& Losonczy-Marshall, M. (2017). Core References in Introductory Social Psychology and Developmental Psychology Textbooks. Psychology Learning \& Teaching, 16(1), 6-18.

Wilson, E. O. (1999). The natural sciences. Consilience: The unity of knowledge. Vintage. p.49-71

Wittgenstein L. (1953) Philosophical investigations. Oxford: Blackwell

Wright, L. K., Cardenas, J. J., Liang, P., \& Newman, D. L. (2017). Arrows in biology: Lack of clarity and consistency points to confusion for learners. CBE-Life Sciences Education, 17(1), ar6.

Zechmeister, J. S., \& Zechmeister, E. B. (2000). Introductory textbooks and psychology's core concepts. Teaching of Psychology, 27(1), 6-11.

Zeman, A. (2001). Consciousness. Brain, 124, 1263-1289.

Zimbardo, P., Johnson, R., \& McCann, V. (2017). Psychology: Core concepts (8th ed.). Hoboken, NJ: Pearson Education.

Zuckerman, H., \& Merton, R. K. (1972). Age, aging, and age structure in science. Higher 